IMR

38,6

1370

Received 10 July 2020

24 February 2021

20 April 2021

8 June 2021

Accepted 10 June 2021
Revised 30 November 2020

\section{Performance implications of export assistance: the mediating role of export entrepreneurship}

Anisur R. Faroque and Olli Kuivalainen

School of Business and Management, LUT University, Lappeenranta, Finland

Jashim Uddin Ahmed

School of Business and Economics, North South University, Dhaka, Bangladesh and InterResearch, Dhaka, Bangladesh

Mahabubur Rahman

Department of Marketing, Rennes School of Business, Rennes, France

Hiran Roy

International School of Hospitality, Sports, and Tourism Management, Fairleigh Dickinson University, Vancouver, Canada

M. Yunus Ali

School of Business, Monash University, Bandar Sunway, Malaysia, and

Md Imtiaz Mostafiz

Sheffield Business School, Sheffield Hallam University, Sheffield, UK

\begin{abstract}
Purpose - Although both institutional export assistance and entrepreneurial orientation (EO) contribute separately and positively to export performance, the interplay between them has received little attention. This study examines the role of international EO in deriving performance benefits from governmental and nongovernmental export assistance.

Design/methodology/approach - In this longitudinal study, two surveys were administered at two different times: In 2011, 705 Bangladeshi apparel exporters were surveyed, and in 2019, a subsequent survey of 198 firms in multiple industries was conducted. The aim of the surveys was to assess the relationships between governmental and nongovernmental assistance, $\mathrm{EO}$ and export performance.

Findings - The results of the first survey show that, while nongovernmental assistance influences performance directly and via EO, governmental assistance has only direct effects. Furthermore, the negative influence of government assistance on EO reduces the total effects and renders them nonsignificant. The results of the second survey demonstrate that government EPPs have both direct and indirect positive and significant effects on market performance, indicating a partial mediation, whereas quasi-governmental assistance has positive and significant direct effects as well as negative but nonsignificant indirect effects. Nongovernmental EPPs have both direct and indirect significant effects on international performance, indicating a partial mediation.
\end{abstract}

Research limitations/implications - The study has important implications for researchers studying export assistance and its impact on firm performance. Instead of adopting a parochial view of government assistance, this study categorizes such assistance into three types - government, quasi-government and

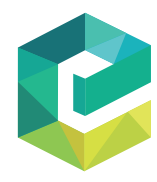

(C) Anisur R. Faroque, Olli Kuivalainen, Jashim Uddin Ahmed, Mahabubur Rahman, Hiran Roy, M. Yunus Ali and Md Imtiaz Mostafiz. Published by Emerald Publishing Limited. This article is published under the Creative Commons Attribution (CCBY 4.0) licence. Anyone may reproduce, distribute, translate and create derivative works of this article (for both commercial and non-commercial purposes), subject to full attribution to the original publication and authors. The full terms of this licence may be seen at http://creativecommons.org/licences/by/4.0/legalcode

The authors would like to acknowledge the North South University (Research Grant, CTRG-19/ SBE/17) and InterResearch (Research Project, 2019), Dhaka, Bangladesh.
International Marketing Review Vol. 38 No. 6,2021 pp. $1370-1399$ Emerald Publishing Limited 0265-1335

DOI 10.1108/IMR-07-2020-0141 
nongovernment. Furthermore, this study bridges the export assistance and international entrepreneurship literature by including EO.

Practical implications - Entrepreneurs must emphasize the use of government assistance in order to enhance export performance. However, to promote both entrepreneurship and performance, they must emphasize nongovernment assistance. Exporters should also capitalize on the assistance extended by various quasi-governmental agencies to bolster export performance.

Originality/value - Given the performance advantage of export assistance, this study highlights the contribution of the private sector in promoting export entrepreneurship while shedding light on the pernicious role of (quasi-)governmental assistance in export entrepreneurship.

Keywords Export assistance, International entrepreneurial orientation, Export performance

Paper type Research paper

\section{Introduction}

The development of export marketing remains a key challenge for both the private and public sectors. The basic tenet is that exporting is an entrepreneurial act (Ibeh and Young, 2001), so export promotion programs (EPPs) conducted by governmental, quasi-governmental and nongovernmental entities must be strongly linked to export entrepreneurship. Consequently, governments design public policies to enable firms to succeed in international markets. National institutional policies influence the incentives and opportunities for which firms innovate and adapt to dynamic environments, with important implications for strategy and entrepreneurship (Holmes et al., 2016). Although scholars acknowledge that nationalEPPs can be instrumental in enhancing entrepreneurial capabilities (Cavusgil and Yeoh, 1994; Leonidou et al., 2015), researchers have ignored this perspective in favor of a parochial focus on the performance implications of EPPs. Likewise, scholars from the export entrepreneurship field have maintained a safe distance from the export assistance literature by focusing exclusively on performance outcomes, despite the complementary nature of these two streams of literature (Faroque and Takahashi, 2012a). Accordingly, this research presents a conceptual framework connecting (international) entrepreneurship literature with export assistance. It also addresses the fundamental question of whether export support-related policies can influence export entrepreneurship to achieve export success.

Research interests are skewed toward the assistance provided by governmental agencies, despite the prevalence of quasi-national and private institutions (Clayton et al., 2018). This insular focus on EPPs has limited our understanding of the relationship between export assistance and performance (Catanzaro et al., 2019; Faroque and Takahashi, 2015; GeldresWeiss and Monreal-Pérez, 2018; Singer and Czinkota, 1994; Wilkinson and Brouthers, 2006). While quasi-government hybrid organizations such as trade and exporters' associations offer a great promise of "greater effectiveness" and "businesslike" functions (Koppell, 2006), private export service organizations such as banks and insurance companies play an active and complementary role in export promotion (Seringhaus and Rosson, 1990). This study contributes to the call for a holistic investigation of the relationship between export assistance, export entrepreneurship and performance across the three aforementioned sets of institutions.

Most prior studies on export assistance that assumed a direct relationship between government EPPs and export performance contribute and lead to misleading policy recommendations. Therefore, a simultaneous analysis of the direct, indirect and total effects of the three types of export assistance would generate additional insights and help explain the equivocal findings of previous studies (Lages and Montgomery, 2005). Those studies that reported an indirect relationship between EPPs and performance have relied on market knowledge, export commitment, network relationships, pricing strategy, market attractiveness and some other general strategy variables (Faroque and Takahashi, 2012a; Haddoud et al., 2017; Lages and Montgomery, 2005; Leonidou et al., 2011; Shamsuddoha and Ali, 2006; Sharma et al., 2018). Given that both internal firm capabilities and external
Performance implications of export assistance 
IMR 38,6

resources affect performance, examining the effects of either internal capabilities or external resources alone is unlikely to provide a holistic view. Moreover, the impact of the abovementioned factors on firm performance, investigated in previous studies, is not attained automatically if no entrepreneurial strategy is in place. Firms must thus have an entrepreneurial orientation (EO) that combines proactive, innovative and risk-taking postures to reap all possible benefits from export assistance. International EO is therefore a better surrogate mediator in the export assistance-export performance relationship than this array of firm-related factors. Consequently, this study investigates the mediating role of international EO - the most widely used firm-level measure of entrepreneurship in an international context - in the relationship between EPPs provided by governmental, quasigovernmental and nongovernmental agencies and export performance.

The proposed mediating role of international EO was tested using two surveys administered in 2011 and 2019. In the first survey, sample firms were drawn from the apparel exporting industry of Bangladesh, an emerging country in South Asia. This focus is important given the underrepresentation of emerging countries in earlier studies (Broocks and Van Biesebroeck, 2017; Haddoud et al., 2017). Bangladesh is currently the second-largest apparel exporting country in the world, following China. Thus, data from Bangladesh comprise a contextual contribution to the limited evidence available on the exporting behavior and assistance requirements of managers in South Asian firms. The results of the first survey [conducted in 2011] demonstrated that the three types of EPPs directly impact both financial and product-market performance, but only nongovernment EPPs positively impact international EO. We found that the nexus between international EO and financial and product-market performance is also positively significant.

In the second survey, conducted in 2019, sample firms were drawn from multiple industries. The second survey was administered mainly for two reasons: first, to enhance the generalizability of the findings of the first survey by assessing in a multi-industry setting; second, to further explore the counterintuitive finding that governmental/quasigovernmental export assistance does not affect international EO. The two rounds of data collection (2011 and 2019) thus provide unique insights into the dark side of export assistance, especially from governmental/quasi-governmental providers. The counterintuitive and deleterious impacts of government/quasi-government assistance on export performance through EO (in the first survey) encouraged us to search for secondary sources (e.g. published articles, newspapers and agency reports) and we found evidence on the clientelistic role of quasi-national assistance providers. Finally, we conducted a second round of data collection, using three separate providers of assistance to isolate the effects of each of the three types of providers. The results of the second survey demonstrated that the nexus between EPPs from the three providers and market performance is positive, which confirmed the findings of the first survey. Furthermore, our results show that while governmental and nongovernmental EPPs positively affect international EO, quasi-governmental EPPs negatively impact international $\mathrm{EO}$.

This study makes two significant contributions to the literature. First, it integrates export assistance-export performance literature with international entrepreneurship (IE) using EO as a theoretical lens. This elucidates the process through which EPPs enhance performance, providing a better understanding of the "black box" between resources and performance. As our understanding of this process is limited, the mere possession of resources cannot guarantee a performance advantage (Miao et al., 2017). In essence, this study highlights the importance of export entrepreneurship in achieving the performance benefits of EPPs. Second, this study adopted a more nuanced approach and differentiated between governmental, quasi-governmental and non-national EPPs, which were found to produce differing outcomes with respect to export performance and international EO. Finally, this study challenges the global positive view of institutional incentives and highlights the 
corrupt practices and power politics of quasi-government exporters' associations in those developing nations that are making strides in the world export market.

\section{Conceptual development and hypotheses}

EPPs and export performance

International entrepreneurial firms in emerging economies endeavor to compensate for resource constraints by developing and bolstering relationships with various governmental, quasi-governmental and nongovernmental entities (Hitt et al., 2000; Karabag and Berggren, 2014; Sim and Ali, 1998). Specifically, these firms endeavor to build firm-specific internal resources and entrepreneurial capabilities while simultaneously capitalizing on external resources provided by the three types of agencies (Freeman et al., 2006; Vasilchenko and Morrish, 2011).

External networks can be partnership- or sponsorship-based (Lee et al., 2001). Sponsorshipbased linkages refer to unilateral relationships (with governmental and quasi-governmental agencies, e.g. nonprofit exporters' associations) where the sponsor commits unilateral support to the firm without expecting/obtaining any explicit rewards in return (Yeoh, 2009). Government-sponsored export assistance, which is provided through various governmental agencies, is designed to (1) create awareness about exporting as an option for growth and market expansion; (2) reduce or remove barriers to exporting; and (3) provide financial and nonfinancial incentives and assistance to potential and existing exporters (Karabag and Berggren, 2014; Seringhaus and Rosson, 1990). In Bangladesh, the context of this study, these agencies include the Ministry of Commerce, the Export Promotion Bureau, governmentowned insurance companies, the Central Bank and six government commercial banks. Conversely, partnership-based linkages denote cooperative bilateral relationships in which partners exchange resources and maintain long-term ties (Yeoh, 2009). Exporters, for instance, rely on various network partners for necessary resources that facilitate export activities, such as bank loans, export-risk-hedging instruments and information about export markets. Nongovernmental/private organizations also play a pivotal role in export promotion by providing exporters with various types of export assistance. However, their role is complementary (Seringhaus and Rosson, 1990) because private organizations are profitoriented and exist on reciprocity whereas the export promotion services of government institutions are unrequitable. Export service organizations, such as banks and insurance companies, actively promote the industry by offering export assistance, such as belowmarket interest rates and special insurance schemes for exporters. These actions help exporters reduce operational costs for export management activities. The export-related services provided by export trading companies include combining all marketing activities, which is related not only to searching for foreign buyers, order collecting and media for the manufacturers, but also to placing orders with suitable manufacturing factories and providing technical and communicational support to buyers and manufacturers (www. textiletoday.com.bd). These trading houses typically possess strong market knowledge and particular competences; their assistance is valued by suppliers and buyers alike (Peng and York, 2001; Rosson and Ford, 1982).

In this study, both sponsorship-based (unilateral: government/quasi-government) and partnership-based (bilateral: bank, insurance companies, export trading firms, etc.) sources are included as EPP providers due to their significant but distinctive roles in export entrepreneurship and performance. Although previous studies have investigated the effect of export assistance on performance, it is requisite for this study to put forth hypotheses linking export assistance to firm performance to develop the conceptual model of the study. Nevertheless, deviating from prior studies that explored the impact of export assistance on performance by lumping together both governmental export assistance and
Performance implications of export

assistance 
IMR

38,6

1374

nongovernmental assistance (e.g. Sousa and Bradley, 2009), which reported mixed findings, this study adopts a nuanced approach, examining the individual effects of governmental/ quasi-governmental and nongovernmental export assistance on performance.

Export assistance programs may improve exporters' financial and nonfinancial performance in multiple ways (Ali and Shamsuddoha, 2014; Karabag and Berggren, 2014; Leonidou et al., 2011). First, the three types of agencies provide export-oriented firms with crucial informational resources via diverse types of information about foreign market structure, competitors' strategy, consumer behavior, etc. (Lages and Montgomery, 2005; Leonidou et al., 2011). Informational assistance includes information relating to foreign market opportunities and threats, as well as trade mobility programs, such as assistance in participating in trade shows and seeking support from trade offices abroad (Francis and Collins-Dodd, 2004; Lages and Montgomery, 2005; Leonidou et al., 2011). It also includes organizing overseas trade missions and trade fairs, helping in establishing contacts with foreign buyers, and providing information about export markets and market trends. Informational assistance ameliorates any information asymmetry between potential exporters and foreign markets, helping the focal firm to strategize efficaciously for the market selection and marketing mix. This positively affects firm performance in the international market (Francis and Collins-Dodd, 2004; Leonidou et al., 2011). For instance, specific information concerning customer expectations enables exporters to effectively develop a marketing mix adaptation strategy. Information concerning customer behavior also enables firms to design an effective product and pricing strategy that promotes customer satisfaction and loyalty, positively affecting sales revenue (Lages and Montgomery, 2005; Leonidou et al., 2011). Second, the export assistance provided by various governmental/quasi-governmental and nongovernmental agencies helps exporters identify and foster relational resources with diverse types of stakeholders, such as foreign importers and distributors in importing countries. More specifically, such assistance helps exporters find compatible foreign partners, such as distributors, assisting them in mitigating the transaction costs associated with exporting activities (Francis and Collins-Dodd, 2004; Leonidou et al., 2011). Consequently, these firms can attain cost-competitive advantages in foreign markets, thereby shoring up their profitability (Lages and Montgomery, 2005; Leonidou et al., 2011). Third, export assistance programs enable exporters to access financial resources in the form of export loans, export credit guarantees, subsidies, insurance and other arrangements, which help them cover financial risks (Catanzaro et al., 2019). Governmental financial assistance is often provided via comprehensive guarantee insurance facilities through export credit guarantee schemes, duty drawback schemes, income tax rebates on export earnings, or the duty-free import of raw materials and machinery (Ahmed and Brennan, 2019). This helps exporters reduce the costs associated with export marketing activities, positively affecting their performance.

It should be noted that financial resources are predominantly provided by various governmental and quasi-governmental entities rather than nongovernmental ones. The latter type of entity provides comparatively less export assistance (in the form of informational and relational resources) due to their partnership-based and informal relationships, in which market knowledge is shared as a social process (Uzzi and Lancaster, 2003). Nevertheless, we propound that nongovernmental assistance also has a positive impact on the performance of exporters. This is expected to happen chiefly because export performance hinges primarily on the acquisition and utilization of germane information pertaining to diverse market-based agents and actors such as customers, distributors and competitors (Lafferty and Hult, 2001; Lengler et al., 2013). Compared to financial support in the form of visible resources (Cooper et al., 1994), relational resources play a more crucial role in shaping both current and future export performance (Zhang and Fung, 2006). In sum, we expect a positive effect of nongovernmental export assistance on export performance. Therefore, we put forth the following hypotheses: 
H1a. The use of EPPs provided by governmental/quasi-governmental agencies has a positive effect on a firm's (a) financial and (b) product-market export performance.

H1b. The use of EPPs provided by nongovernmental entities has a positive effect on a firm's (a) financial and (b) product-market export performance.
Performance implications of export

assistance

\section{EPPs and international EO}

EO as firm-level entrepreneurship, characterized by firms' innovative, proactive and risktaking behavior (i.e. part of corporate entrepreneurship: Ireland et al., 2009), has emerged in the entrepreneurship literature (Covin et al., 2006) as an alternative to individual- and grouplevel analyses. International EO (Knight and Cavusgil, 2004) is a subcategory of the general EO concept with an additional "international" emphasis (Covin and Miller, 2014). This concept is widely accepted and integrated in IE as "a combination of innovative, proactive and risk-seeking behavior that crosses national borders and is intended to create value in organizations" (McDougall and Oviatt, 2000, p. 903).

In general, exporters based in emerging economies face challenges such as a lack of financial and informational resources and an aversion to risk-taking (Freeman et al., 2006). However, in today's competitive marketspace, firms do not necessarily need to own assets (Al-Aali and Teece, 2014); they can instead overcome these challenges by mobilizing and orchestrating resources from external sources such as various governmental, quasigovernmental and nongovernmental agencies (Freeman et al., 1983; Oviatt and McDougall, 1994).

Information acquisition is "the most important element of market information processing because without it there is no opportunity for the firm to keep abreast of its customer and competitor environments" (Sinkula et al., 1997, p. 308). The market-based information extended by the three types of entities mentioned above provides the basis for shared values and beliefs in firms, determines norms of behavior, and helps employees better understand their environment and organization (Harmancioglu et al., 2010). This allows firms to respond to environmental changes proactively by providing innovative solutions with sufficient risktaking (Putninsš and Sauka, 2020). The market information firms acquire from external parties helps them identify future trends, latent customer needs, and emerging business opportunities that they can incorporate into their strategic stance (Cao et al., 2006; Collins and Clark, 2003) and market development process. Events such as trade shows organized by governmental and nongovernmental agencies help exporters find compatible foreign partners and develop relationships with a wide array of pertinent actors and agents in foreign markets (Haddoud et al., 2017). That is to say, the three types of support help exporters build and bolster relational assets. The export marketing assistance provided by such diverse entities thus facilitates market knowledge gathering, encourages risk-taking and proactive opportunity-seeking behavior in foreign market involvement, stimulates firms' interest in and commitment to exporting, and serves as an external resource for building the knowledge and experience vital for foreign market entry (Seringhaus, 1986). This suggests a direct link between export marketing assistance and exporters' innovative, proactive and risk-taking behavior.

Government- and quasi-government-supported and -sponsored informational (e.g. seminars and published reports) as well as experiential programs (e.g. trade fairs and trade missions) may broaden exporters' knowledge of specific markets, buyers' specific needs and competitors' strategies. This in turn helps managers proactively exploit anticipated changes in export markets by meeting emerging market demands (Acosta et al., 2018; Kim et al., 2020; Malca et al., 2020). Furthermore, such programs have a positive impact on promoting and developing new products/services by utilizing new methods and technologies to meet emerging market demands (Cillo et al., 2010). Perceptions of uncertainty and risk 
IMR

38,6

1376

change during experiential learning, which means that risk taking and coping with uncertainty are not static phenomena; rather, they are dynamic processes that can be influenced by the type and intensity of experiential knowledge (Arpiainen and Kurczewska, 2017) gathered from trade fairs and trade missions. Exporters increase their risk-taking propensity by strengthening the business, political and community network ties (Danso et al., 2016) developed through participating in these programs. External networks with industry partners and governmental/quasi-governmental agencies serve as agents for social influence and shape executives' frames of reference, affecting which entrepreneurial policies and practices firms adopt (Geletkanycz and Hambrick, 1997).

In addition to marketing assistance, the financial assistance provided by governmental agencies may help entrepreneurial exporters strengthen their entrepreneurial behavior and managerial strategic actions by financing new product development, export-related costs, providing insurance against export risks, and upgrading production and facilities. In general, well-developed and functioning institutions promote efficiency and encourage risk-taking and innovation (Roxas and Chadee, 2013). Governments influence both the supply and demand sides of entrepreneurship (Cumming et al., 2017; Verheul et al., 2002). They have a positive effect on the quantity of entrepreneurship (Chowdhury et al., 2019), IE (Chowdhury et al., 2015) and the quality of entrepreneurship in transforming a risk-averse culture into a vibrant entrepreneurial risk-taking culture (Bhasin, 2007). This could be extended to assistance provided by entities other than the government in an export setting. Based on the preceding discussion, we postulate the following hypothesis:

H2a. The use of EPPs provided by governmental/quasi-governmental agencies has a positive effect on a firm's international EO.

Although nongovernmental agencies provide little financial support, the informational and relationship building support provided by these agencies is expected to significantly affect a firm's EO (Dai and Si, 2018), because the more market-based information a firm possesses, the more confidently it will be able to proactively engage in high-risk and high-return ventures (Barney et al., 2011; Foss, 2011; Srivastava et al., 2001). Relationship-building support extended by nongovernmental agencies facilitates the identification of compatible foreign partners (Haddoud et al., 2017), which is expected to bolster firms' EO (Barbaroux, 2014; Courtney et al., 2017). Hence, the following hypothesis is suggested:

$H 2 b$. The use of EPPs provided by nongovernmental entities has a positive effect on a firm's international EO.

\section{International EO and export performance}

Entrepreneurial exporters are characterized by the EO dimensions of innovativeness, being proactive and risk taking (Freeman et al., 2006; Karami et al., 2020; Luo and Tung, 2007; Morrish, 2011). Innovativeness induces firms to design and launch novel products to meet customer expectations in foreign markets; this engenders customer loyalty and helps firms gain and bolster their shares of foreign markets (Covin and Miller, 2014; Dai et al., 2014). These firms must be innovative in orchestrating resources to overcome their firm-specific resource limitations (Fernández-Mesa and Alegre, 2015; Karami et al., 2020). They can create new strategic resources by amalgamating various internal and external resources, which will help them develop a competitive advantage in the international marketplace (FernándezMesa and Alegre, 2015; Lisboa et al., 2011). Innovativeness also enables these firms to develop novel, market-driven products and promotion strategies for export markets (Karami et al., 2020; Lisboa et al., 2011) and to configure and reconfigure marketing strategies in keeping with marketplace dynamics, such as changes in the intensity and nature of their competition. In other words, innovative firms are better able to adapt to changes in the international 
market, resulting in superior firm performance (Fernández-Mesa and Alegre, 2015; Karami et al., 2020). Furthermore, the innovativeness of international EO firms enables them to formulate and execute unique promotional campaigns that resonate with customers, positively affecting firm performance (Fernández-Mesa and Alegre, 2015; Karami et al., 2020; Lisboa et al., 2011).

The proactive nature of international EO induces firms to explore new potential foreign markets for their products, enabling them to expand their foreign market portfolio (market breadth) and diversify the risk associated with export marketing (Acosta et al., 2018; Covin and Miller, 2014; Karami et al., 2020; Lisboa et al., 2011). Proactive firms are constantly in search of new market opportunities for their products, which fundamentally lessens their reliance on a specific set of foreign markets; this augments revenue-generating potential and reduces performance volatility (Kuivalainen et al., 2007; Lisboa et al., 2011). Similarly, the proactive nature of international EO induces firms to exploit existing foreign markets to further penetrate those markets and attain better market depth in the existing markets (Fernández-Mesa and Alegre, 2015; Karami et al., 2020; Kuivalainen et al., 2007; Lisboa et al., 2011). Consequently, better market breadth and market depth help international EO firms enhance the profitability of their export marketing activities (Acosta et al., 2018; Covin and Miller, 2014; Dai et al., 2014; Lisboa et al., 2011).

Risk-taking is viewed as one of the momentous facets of EO (Fernández-Mesa and Alegre, 2015; Kuivalainen et al., 2007; Lisboa et al., 2011). While non-entrepreneurial firms tend to eschew risky projects, entrepreneurial firms proactively gauge the risks and returns associated with potential business ventures. This proactive and calculated approach to exploring business opportunities enables entrepreneurial exporters to find and enter new foreign markets (Fernández-Mesa and Alegre, 2015; Karami et al., 2020; Lisboa et al., 2011). In other words, taking risks can facilitate the attainment of a first-mover advantage in some new foreign markets, which in turn helps such firms build brand equity and gain a bigger share of the market (Fernández-Mesa and Alegre, 2015; Kuivalainen et al., 2007). Entrepreneurial firms reap rewards in the form of superior financial and nonfinancial performance (Karami et al., 2020; Kuivalainen et al., 2007; Lisboa et al., 2011). Therefore, the following hypothesis is postulated:

H3. A firm's international EO has a positive effect on its (a) financial and (b) productmarket export performance.

\section{The mediating role of international EO}

Resources alone are not enough to enhance firm-level performance; they must be leveraged through capabilities (Szulanski, 1996), the transformational processes by which resources are utilized and converted into an organization's output (Dutta et al., 2005). Specifically, "the capability-building mechanism affects economic profit only after the acquisition of resources and can not do so if such resource acquisitions fail to materialize" (Makadok, 2001, p. 389; emphasis in original). Sustainable competitive advantage hinges not only on the type of resources a firm owns but also on how it integrates, configures, and transforms such resources using the appropriate capabilities (Teece et al., 1997). The export assistance provided by the three types of agencies is considered a resource in terms of managers' ability to develop capabilities in exporting, but it must be considered in the context of other intervening variables (Sharma et al., 2018), such as EO.

We contend that resources mobilized via EPPs have no value if they are not integrated and utilized through the firm's innovativeness, proactiveness and risk-taking capabilities. EO acts as an integration mechanism that facilitates the innovative use of resources, proactive search for product-market opportunities, and risk-taking in investing resources in productive outcomes. The integration mechanism inherent in EO fosters a performance advantage by 
IMR

38,6

1378

linking previously unconnected external resources (Cohen and Levinthal, 1990). More specifically, we argue that the various resources provided by governmental/quasigovernmental and nongovernmental agencies will positively affect firms' international EO, which will subsequently affect their financial and nonfinancial performance. Export assistance prompts firms to embark on innovative initiatives to seek opportunities in new foreign markets and renew their strategies in existing markets, thus enhancing positive financial and nonfinancial performance. In sum, EO provides an export firm with the ability to "reconfigure a firm's resources and routines in the manner envisioned and deemed appropriate by its principal decision-makers" (Zahra et al., 2006, p. 918), highlighting the role of firms' international EO. International EO induces firms to use resources (Chirico et al., 2011) mobilized through EPPs in a more efficient and effective manner to enhance performance in the international market. Therefore, the following hypotheses were developed:

H4a. The positive relationship between governmental/quasi-governmental EPPs and (a) financial and (b) product-market export performance is mediated by international $\mathrm{EO}$.

H4b. The positive relationship between nongovernmental EPPs and (a) financial and (b) product-market export performance is mediated by international EO.

\section{Research methodology \\ Sample}

The export-oriented apparel industry of Bangladesh, the world's second-largest apparel export sector, was used as the research context for this study. From its initial start in the early 1980 s, this industry has spawned over 4,000 export start-ups, accounts for $80 \%$ of the country's manufacturing exports, and has created over 3 million jobs. The companies operating in this industry are mostly early internationalizing firms that have focused on global markets and are particularly appropriate for testing the research framework. The study sample was therefore drawn from all the exporting apparel firms in the country. For the first survey 800 exporters were randomly selected from the members' directories of the Bangladesh Garment Manufacturers' and Exporters' Association. All the firms in the industry are export start-ups that export mainly to countries in the European Union and North America.

\section{Data collection and screening}

Data were collected in 2011 through a face-to-face survey method, mostly because the response rate for mail surveys is relatively low in developing countries (Shamsuddoha and Ali, 2006). This resulted in 718 completed questionnaires (a response rate of approximately $90 \%$ ), 705 of which were retained after checking for missing values, outlier cases and applying a rigorous normality test in SPSS 26 (required for structural equation modeling with maximum likelihood estimation).

Given that the data were collected from a single informant in each firm, this study may suffer from common method variance (CMV). However, efforts were made to minimize this bias, following suggestions in prior studies (Jap, 2001; Podsakoff et al., 2003). Two statistical tests were used to identify the possibility of CMV. First, the post hoc Harman's one-factor test showed that a single factor accounted for only $21 \%$ of variance, suggesting that the presence of CMV is unlikely. Second, a marker variable was used as a technique proposed by Lindell and Whitney (2001) to tackle CMV. We used "founder's prior international business experience before starting this business" as the marker variable because it is theoretically 
unrelated to any of the constructs of this study. CMV was found to not be a potential threat in this study because it was non-significantly or extremely marginally correlated with the other constructs of the study.

The unit of analysis used in this study was the firm, which is in line with our theory because we assessed export performance at the firm rather than the export venture level with an export function level theory (Oliveira et al., 2012). It is also common in the export performance and export promotion literature to report firm-level performance data (e.g. Ahmed and Brennan, 2019; Catanzaro et al., 2019; Malca et al., 2020; Nakku et al., 2020).
Performance implications of export

assistance

1379

\section{Measurement of variables and research instrument development}

Use of government, quasi-government and nongovernment EPPs was measured using the financial and marketing dimensions. Respondents were asked to indicate the level of assistance they had used in the last three years on a seven-point scale (from "none" to "substantial"). International EO was measured using scales established in the entrepreneurship and IE literature (Knight and Cavusgil, 2004; Lumpkin and Dess, 2001). Respondents were asked to represent their firm's position by rating the statements on a seven-point scale (from "strongly disagree" to "strongly agree"). As the objective of this study is to investigate how international $\mathrm{EO}$ is related to export assistance and performance rather than the unique influence of its individual dimensions, a composite of international $\mathrm{EO}$ was adopted (Wales $e t a l ., 2013)$. Financial export performance was measured using the three most common items in the export performance literature - export sales volume, export sales growth and export profitability. Product-market export performance was measured by two items - new market entry and new product introduction in export markets (Katsikeas et al., 2000).

The structured questionnaire used for the survey was comprehensively developed using measurement items drawn from the extant literature and a pilot study. Four academic experts assessed the content validity of the items. The questionnaire was originally written in English and translated into Bengali. The translation was checked by a bilingual academic before using the standard procedure of back translation to ensure "translation equivalence" (Van de Vijver and Leung, 1997). The questionnaire was then pretested with 15 ownermanagers and further revised based on their feedback. In addition, firm size (number of employees), firm age and export market coverage (number of markets exporting to) were included as control variables to better understand the relationships hypothesized in this study.

\section{Method of data analysis}

For analytical purposes, structural equation modeling (SEM) with AMOS 26 was used. This technique is appropriate because some of the study variables were simultaneously dependent and independent (Hair et al., 2010). Moreover, SEM allowed us to measure the indirect and total effects among the constructs. The structural equation model has the two following components: (1) the measurement model, which reduces the observed variable to a smaller number of latent factors while satisfying the validity of the measures and (2) the structural model, which specifies the causal relationships among the latent variables.

\section{Sample characteristics}

The key informants of the survey included the founder, managing director, marketing director, and senior marketing or export executive with sufficient knowledge of exporting activities and managerial policies of their firm, as well as the use of governmental and nongovernmental assistance by the firm. Among the respondents, $21 \%$ reported having up to 
IMR

38,6

5 years of industry experience, 34\% reported having 6-10 years of experience, and the remaining $45 \%$ reported having over 10 years of industry experience. Approximately $60 \%$ of respondents had been with their current firm for up to 5 years, $29 \%$ had been there for 6-10 years, and the remaining $11 \%$ had been there for more than 10 years. In terms of export market coverage, $25 \%$ of the firms exported to up to three international markets, $34 \%$ exported to 4-6 markets, $20 \%$ exported to $7-9$ markets, and the remaining $21 \%$ exported to 10 or more markets.

\section{Analyses and results}

Following Gerbing and Hamilton (1996), exploratory factor analysis in SPSS 26 was used followed by confirmatory factor analysis (CFA), and SEM in AMOS 26. Several items with low factor loadings or high cross-loadings were excluded. The remaining items were analyzed in the CFA to verify the hypothesized factor structure and assess convergent and discriminant validity.

\section{Measurement model}

Table 1 presents the construct measurement, CFA results and construct reliability. Table 2 shows the correlation matrix and descriptive statistics for the constructs. The factor loadings in the measurement model were all significant and greater than 0.50 (Hatcher, 2007), indicating convergent validity. Discriminant validity was assessed by the condition of whether the square root of the average variance extracted (AVE) of each construct was higher than the correlations between this and any other constructs in the model (Fornell and Larcker, 1981). The diagonal elements of the correlation matrix in Table 2 were all greater than the off-diagonal elements. Thus, the measurement model demonstrates adequate discriminant validity, suggesting that the four constructs used in the model belong to distinct and separate entities.

Construct reliability was estimated using composite reliability $(\mathrm{CR})$ and AVE. The alpha values and $\mathrm{CR}$ scores of all the constructs exceeded the recommended threshold of 0.70 , indicating that the constructs had high internal reliability (Fornell and Larcker, 1981). Excepting the AVE of export performance, the AVE coefficients were all greater than 0.50, indicating that the items explain the variance in the constructs (Fornell and Larcker, 1981). The AVE of export financial performance was only slightly lower, at 0.49; Hatcher (2007) suggested that reliabilities can be acceptable even if AVE estimates are less than 0.50. Many studies have reported lower AVE values (e.g. 0.40 in Wilden et al. (2013), for dynamic capability; 0.47 in Kenny and Fahy (2011), for international performance). Thus, a slightly lower value does not necessarily rule out the reliability of a construct.

Finally, the measurement model shows acceptable fit indices for the root mean square error of approximation (RMSEA: 0.073), standardized root mean square residual (SRMR: 0.050), goodness-of-fit index (GFI: 0.932), comparative fit index (CFI: 0.912) and incremental fit index (IFI: 0.913), which provided sufficient proof of model fit.

\section{Structural model}

SEM was used to simultaneously estimate the conceptual framework of the study using the maximum likelihood estimation in AMOS 26. We first investigated the direct effects of EPPs on export performance and then the mediation effects of international EO in the relationship between EPPs and export performance. All the fit indices for models with direct and mediated effects exceeded the minimum cut-off value of 0.90; the RMSEA and SRMR values were below the maximum level of 0.10 (Hair et al., 2010), providing satisfactory proof of model fit (Browne and Cudeck, 1992) (see Table 3). 


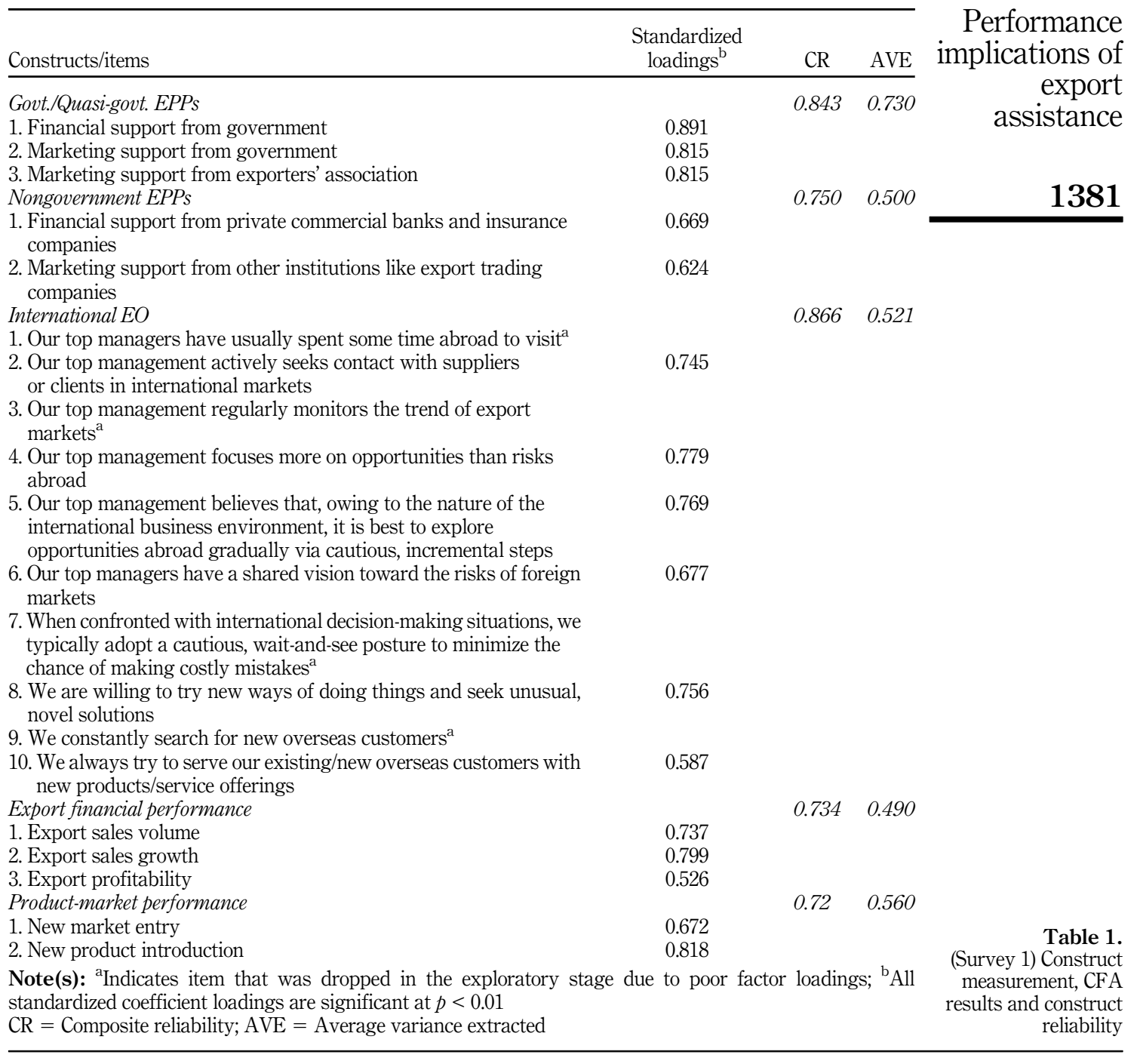

Direct effects. We examined the direct effects of EPPs on financial and product-market performance using a four-factor structural model (Figure 1). The standardized path coefficients revealed that both government/quasi-government and nongovernment EPPs have a significant and positive impact on both financial and product-market performance. This supports H1a and H1b.

Indirect effects. The mediation effect of international $\mathrm{EO}$ was examined for the relationship between government/quasi-government and nongovernment export assistance and financial and product-market performance. The indirect effects of the exogenous variables on the relevant endogenous variables were estimated with a 95\% confidence level using the bootstrapping method; this was done following Chin's (1998) approach with 1,000 re-samples, as recommended by Davidson and MacKinnon (2001). The results of direct effects are 
IMR

38,6

Table 2.

(Survey 1) Correlations and descriptive statistics
Variables

(1) Govt./quasi-govt. EPPs

(2) Non-govt. EPPs

(3) International EO

(4) Financial performance

(5) Product-market performance

(6) Firm age

(7) Firm size

(8) Market coverage

Mean

SD
(1) (2) (3)

(4)

(5)

(6)

(7)

(8)

0.854

0.465

0.135

0.707

0.265

0.344

0.241

0.270

0.294

0.351

0.244

0.722

0.460

0.373

0.201

0.256

0.265

0.231

0.231

0.235

$\begin{array}{lll}4.121 & 5.01 & 5.173\end{array}$

$1.800 \quad 1.293$

0.971

0.700
0.372
0.417
0.322
4.991
1.012

0.750

$0.372 \quad 0.331$

$0.417 \quad 0.365$

$0.322 \quad 0.312$

$4.991 \quad 4.4$

$1.012 \quad 1.20$

-
0.430
0.212
3.01
0.81

0.132

$\begin{array}{ll}7.6 & 4.0\end{array}$

Note(s): (1) Correlations greater than 0.13 are significant at the 0.05 level. Correlations greater than 0.17 are significant at the 0.01 level; (2) Diagonal is the square root of the average variance extracted (AVE)

\begin{tabular}{lcc}
\hline Statistic & Model for direct effect & Model with mediator \\
\hline$\chi^{2}$ & 340.203 & 457.667 \\
$\mathrm{df}$ & 75 & 180 \\
$\chi^{2} / \mathrm{df}$ & 4.536 & 2.542 \\
Root mean square error of approximation (RMSEA) & 0.084 & 0.060 \\
Standardized root mean square residual (SRMR) & 0.060 & 0.045 \\
Goodness-of-fit index (GFI) & 0.920 & 0.926 \\
Comparative fit index (CFI) & 0.926 & 0.905 \\
Incremental fit index (IFI) & 0.930 & 0.903
\end{tabular}

Table 3.
(Survey 1) Fit statistics for direct effect and mediation effect models Incremental fit index (IFI)

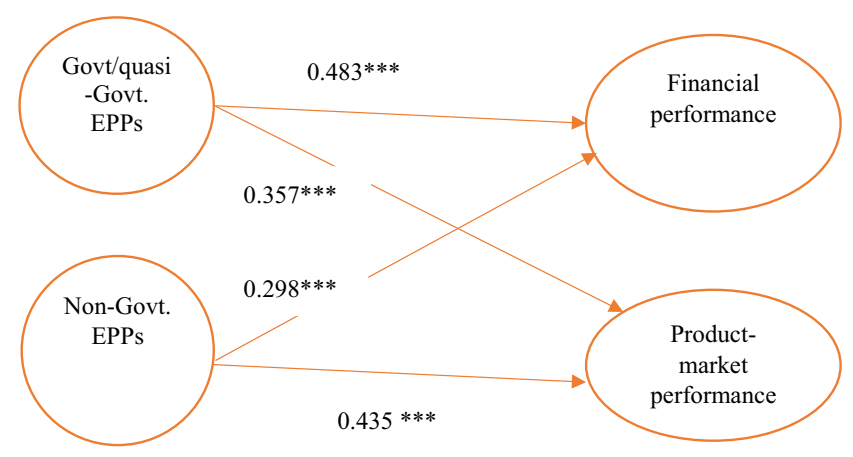

Note(s): Sig. Level $* * *=p<0.001$ (Survey 1)
Figure 1.

Results of direct effect model 


\begin{tabular}{|c|c|c|c|c|}
\hline Hypothesis & Path & Direct effect & & \\
\hline $\mathrm{H1a}(\mathrm{a})^{+}$ & Govt/quasi-govt. EPPs $\rightarrow$ Financial performance & $0.111 *$ & & ex \\
\hline $\mathrm{H} 1 \mathrm{a}(\mathrm{b})^{+}$ & Govt/quasi-govt. EPPs $\rightarrow$ Product-market performance & $0.274 *$ & & \\
\hline $\mathrm{H} 1 \mathrm{~b}(\mathrm{a})^{+}$ & Non-govt. EPPs $\rightarrow$ Financial performance & $0.164^{*}$ & & assistanc \\
\hline $\mathrm{H} 1 \mathrm{~b}(\mathrm{~b})^{+}$ & Non-govt. EPPs $\rightarrow$ Product-market performance & $0.148^{*}$ & & \\
\hline $\mathrm{H} 2 \mathrm{a}$ & Govt/quasi-govt. EPPs $\rightarrow$ International EO & -0.051 (ns) & Not supported & \\
\hline $\mathrm{H} 2 \mathrm{~b}$ & Non-govt. EPPs $\rightarrow$ International EO & $0.395 * * *$ & Supp & 1383 \\
\hline H3(a) & International EO $\rightarrow$ Financial performance & $0.429 * * *$ & Supported & \\
\hline $\mathrm{H} 3(\mathrm{~b})$ & International EO $\rightarrow$ Product-market performance & $0.388^{* * * *}$ & Supported & \\
\hline \multicolumn{4}{|c|}{$\begin{array}{l}\text { Note }(\mathbf{s}):{ }^{+} \text {These hypotheses are already supported in the direct effect model (Figure } 1 \text { ) } \\
\begin{array}{c}*=p<0.05 ; * *=p<0.01 ; * * *=p<0.001 \\
\text { ns }=\text { not significant }\end{array}\end{array}$} & $\begin{array}{r}\text { (Survey 1) Direct } \\
\text { effects in mediation } \\
\text { structural model }\end{array}$ \\
\hline
\end{tabular}

This is in line with hypothesis $\mathrm{H} 4 \mathrm{~b}(\mathrm{a}, \mathrm{b})$. However, no indirect association between governmental/quasi-governmental EPPs and export financial and product-market performance was observed, which means that $\mathrm{H} 4 \mathrm{a}(\mathrm{a}, \mathrm{b})$ was not supported; thus, the relation between governmental/quasi-governmental EPPs and export performance is only direct. Surprisingly, despite the positive direct effect of government/quasi-government EPPs on export financial performance, the total effect is nonsignificant because of the negative (but nonsignificant) indirect effect of government/quasi-government EPPs on financial performance. In the case of product-market performance, although the direct and total effects were significant, the latter was lower than the direct effect due to a negative (but nonsignificant) indirect effect. Figure 2 shows the direct and mediated effects from the mediation effect model. Regarding control variables, the results show that firm size and market coverage had a significant impact on financial performance $(\beta \mathrm{S}=0.168$ and 0.214 , $p<0.05$ respectively), but firm age did not have a significant impact on either of the performance indicators.

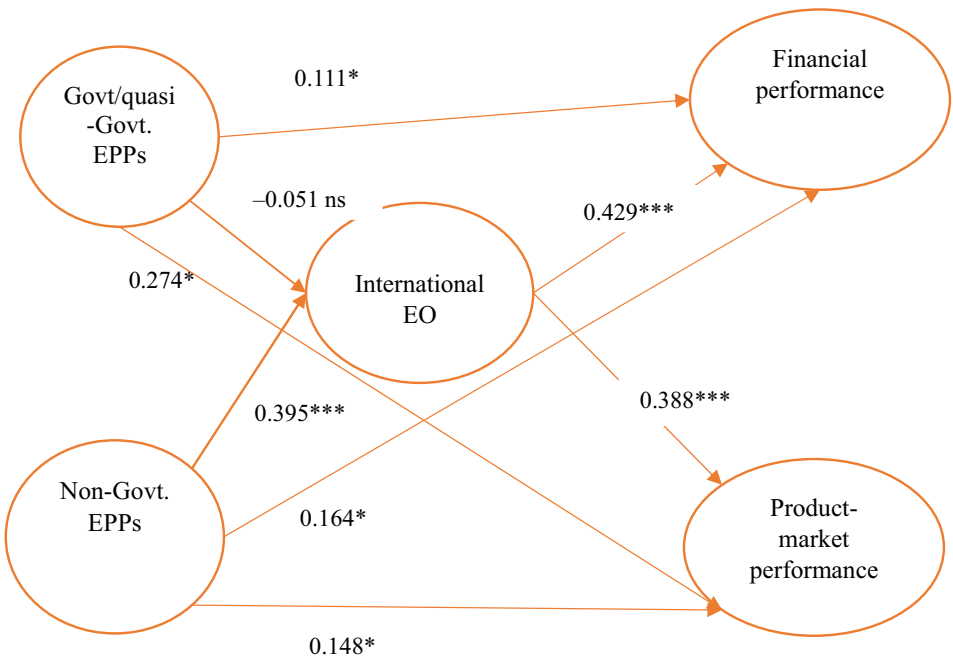

Note(s): Sig. Level $*=p<0.05 ; * *=p<0.01 ; * * *=p<0.001 ;$ ns $=$ not significant (Survey 1)

Figure 2.

Results of mediation structural model 
IMR

38,6

1384

Finally, as an additional robustness check, we conducted a multigroup analysis by AMOS comparing the market coverage of the firms from Survey 1. The dataset was divided into two groups according to the number of markets served: Group 1 (1-6 markets: 385) and Group 2 ( $\geq 7$ markets: 262 ). The analysis showed no significant differences between the groups.

Follow-up survey. In 2019, we administered a follow-up survey to exporters in multiple industries, including apparel, software and pharmaceuticals. This second survey was administered mainly for two reasons: first, to enhance the generalizability of our original findings by surveying in a multi-industry setting; and second, to further explore the counterintuitive finding that governmental/quasi-governmental export assistance has no effect on international EO. Recently, Ahmed et al. (2014) showed that effective industrial policies can be pursued in contexts with weak governance, widespread corruption, and competitive clientelism, as evidenced by the role of exporters' associations in Bangladesh. Ahmed et al. (2014) reported that particular political settlements between the government and the quasi-government exporters' associations in Bangladesh has created a paradoxically viable environment in which the apparel sector has grown and corruption is not unpredictable, and thus does not hamper growth. Therefore, we assumed that while corruption and bribery may not have negatively influenced export growth and performance, they must have affected the entrepreneurial behaviors of exporters, making room for opportunistic behaviors. This compelled us to separate quasigovernment EPPs from government EPPs to single out their individual and differential impacts as opposed to their combined effects, which were evaluated in Survey 1. We classified EPPs into three categories - the informational, financial, and experiential (see definition in Table 5) aid received from the three different groups. Using random sampling and in-person surveys, we received 198 responses from 500 firms, comprising an effective response rate of $40 \%$. The constructs and items of the questionnaire (along with their sources) are presented in Table 5.

To reduce model complexity, we simplified the multidimensional international EO construct by creating a single indicant after averaging the items, as done by other researchers in the field (e.g. Sundqvist et al., 2012). Export performance was measured using eight items related to market performance. We used a similar approach and procedure to analyze data using AMOS 26, as reported earlier. The validity and reliability of the constructs are delineated in Tables 5 and 6 . The correlations and descriptive statistics are presented in Table 7. Both the direct and mediation effect structural models showed satisfactory model fit (Table 8). The results of the direct effect model are depicted in Figure 3, and the direct and indirect effects from the mediation structural model are reported in Table 9.

\begin{tabular}{|c|c|c|c|c|c|}
\hline Hypothesis & Path & $\begin{array}{l}\text { Direct } \\
\text { effect }\end{array}$ & $\begin{array}{l}\text { Indirect } \\
\text { effect }\end{array}$ & $\begin{array}{l}\text { Total } \\
\text { effect }\end{array}$ & Mediation \\
\hline $\mathrm{H} 4 \mathrm{a}(\mathrm{a})$ & $\begin{array}{l}\text { Govt/quasi-govt EPPs } \rightarrow \\
\text { international EO } \rightarrow \text { financial } \\
\text { performance }\end{array}$ & $0.111^{*}$ & $-0.022(\mathrm{~ns})$ & 0.089 (ns) & $\begin{array}{l}\text { No } \\
\text { mediation }\end{array}$ \\
\hline $\mathrm{H} 4 \mathrm{a}(\mathrm{b})$ & $\begin{array}{l}\text { Govt/quasi-govt EPPs } \rightarrow \\
\text { international EO } \rightarrow \text { product-market } \\
\text { performance }\end{array}$ & $0.274^{*}$ & -0.020 (ns) & $0.250 *$ & $\begin{array}{l}\text { No } \\
\text { mediation }\end{array}$ \\
\hline $\mathrm{H} 4 \mathrm{~b}(\mathrm{a})$ & $\begin{array}{l}\text { Non-govt. EPPs } \rightarrow \text { international EO } \\
\rightarrow \text { financial performance }\end{array}$ & $0.164^{*}$ & $0.165^{*}$ & $0.329 * * *$ & $\begin{array}{l}\text { Partial } \\
\text { mediation }\end{array}$ \\
\hline $\mathrm{H} 4 \mathrm{~b}(\mathrm{~b})$ & $\begin{array}{l}\text { Non-govt. EPPs } \rightarrow \text { international EO } \\
\rightarrow \text { product-market performance }\end{array}$ & $0.148^{*}$ & $0.343^{* *}$ & $0.491 * * *$ & $\begin{array}{l}\text { Partial } \\
\text { mediation }\end{array}$ \\
\hline \multicolumn{6}{|c|}{ Note(s): $\mathrm{ns}=$ not significant; $*=p<0.05 ; * *=p<0.01 ; * * *=p<0.001$} \\
\hline
\end{tabular}

Table 5.

(Survey 1) Indirect effects in mediation structural model

Note(s): ns $=$ not significant; $*=p<0.05 ; * *=p<0.01 ; * * *=p<0.001$ 
Standardized loadings ${ }^{\mathrm{b}}$

Use of EPPs: How would you rate the export assistance and support in terms of experiential, informational and financial* aid received from the following in last 3 years?

Govt. EPPS (from govt agencies, govt. owned banks, other govt institutes) $(1=$ none $\ldots \ldots 7=$ substantial $)$

1. Export financial assistance

2. Export experiential assistance

3. Export informational assistance

Quasi-govt. EPPS (exporters' associations) $(1=$ none.....

$7=$ substantial)

1. Export financial assistance

2. Export experiential assistance

3. Export informational assistance

Non-govt. EPPS (from private commercial banks, insurance companies, distributors, customers/clients, export trading companies/

intermediaries $)(1=$ none $\ldots \ldots 7=$ substantial $)$

1. Export financial assistance

2. Export experiential assistance

3. Export informational assistance

Proactiveness (Kuivalainen et al., 2007; Wang, 2008) $(1$ = strongly disagree ..... $7=$ strongly agree)

1. We seek to exploit anticipated changes in our export market ahead of our rivals

2. We act opportunistically to shape the export environment in which we operate

3 . We consistently try to position ourselves to meet emerging export market demands

Risk taking (Jambulingam et al., 2005; Wang, 2008) (1 = strongly

disagree $\ldots \ldots 7=$ strongly agree)

4. Top export managers of our company, in general, tend to invest in high-risk export projects

5 . This company shows a great deal of tolerance for high-risk export projects

6. Our export strategy is characterized by a strong tendency to take risks

7. Taking chances is part of our export business strategy

Innovativeness (Jambulingam et al., 2005) $(1=$ strongly disagree . . . . . . $7=$ strongly agree)

8. Our company is known as an innovator among businesses in our industry

9. We promote new, innovative product/services in our company

10. Our company provides leadership in developing new products/ services

11. Our company is constantly experimenting with new products/ services

12. We have built a reputation for being the best in our industry to develop new methods and technologies

Market performance (Leonidou et al., 2011) (1 = strongly disagree ... $\ldots 7=$ strongly agree)

1. Satisfaction with acquiring new export customers

2. Satisfaction with new export market entry

3. Satisfaction with performance in strategically important target markets
Performance implications of export assistance

$0.826 \quad 0.616$

0.876

0.675

$0.88 \quad 0.711$

0.870

0.875

0.781

$0.855 \quad 0.66$

0.884

0.737

0.816

$0.85 \quad 0.65$

0.771

0.801

0.843

$0.78 \quad 0.48$

0.668

0.623

0.750

0.724

$0.82 \quad 0.48$

0.698

0.726

0.673

0.672

0.676

$0.912 \quad 0.566$

0.690

0.762

0.714
Table 6.

(Survey 2) Construct measurement, CFA results, and construct reliability 
$\begin{array}{lc}\text { Constructs/items } & \begin{array}{c}\text { Standardized } \\ \text { loadings }\end{array} \\ \text { b } & \end{array}$

CR AVE

4. Satisfaction with providing superb value to export customers $\quad 0.795$

5. Satisfaction with retaining valued export customers 0.769

6. Satisfaction with company reputation among export customers $\quad 0.800$

$\begin{array}{lll} & \text { 7. Satisfaction with export customers' satisfaction } & 0.746 \\ & \text { 8. Satisfaction with delivering exactly what export customers want } & 0.738\end{array}$

Note(s): Indicates item that was dropped in the exploratory stage due to poor factor loadings; ${ }^{b}$ All standardized coefficient loadings are significant at $p<0.01$

$\mathrm{CR}=$ Composite reliability; $\mathrm{AVE}=$ Average variance extracted

*(i) Informational assistance: is general in nature and available in print form from government agencies, embassies, or trade missions, exporters' associations, etc. Includes workshops and training related to foreign market opportunities and customer information

(ii) Experiential assistance: is achieved through personal contact through mediation of government or nongovernment entity-supported or sponsored trade fair, trade mission

Table 6.

(iii) Financial assistance: is provided in the form of funds transferring facility, export credit guarantees, and export loans at preferential rates

\begin{tabular}{lccccccc}
\hline Variables & $(1)$ & $(2)$ & (3) & (4) & (5) & (6) & (7) \\
\hline (1) Govt. EPPs & 0.785 & & & & & & \\
(2) Quasi-govt. EPPs & 0.440 & 0.84 & & & & & \\
(3) Non-govt. EPPs & 0.476 & 0.487 & 0.81 & & & & \\
(4) EO & 0.271 & 0.147 & 0.338 & - & & & \\
(5) Market performance & 0.226 & 0.140 & 0.343 & 0.448 & 0.75 & & \\
(6) Age & 0.227 & 0.241 & 0.251 & 0.122 & 0.067 & - & \\
(7) Size & 0.347 & 0.277 & 0.271 & 0.242 & 0.132 & 0.536 & - \\
(8) Industry & 0.061 & 0.047 & 0.128 & 0.040 & 0.034 & 0.240 & 0.154 \\
Mean & 4.5 & 4.56 & 5.04 & 5.15 & 5.56 & 2.91 & 6.6 \\
SD & 1.40 & 1.45 & 1.37 & 1.012 & 1.02 & 0.77 & 2.13
\end{tabular}

Table 7 .
(Survey 2 ) correlations and descriptive statistics

Note(s): (1) Correlations greater than 0.13 are significant at the 0.05 level. Correlations greater than 0.17 are significant at the 0.01 level; (2) Diagonal is the square root of the average variance extracted (AVE)

\begin{tabular}{lcc}
\hline Statistic & Model for direct effect & Model with mediator \\
\hline$\chi^{2}$ & 286.934 & 355.988 \\
$\mathrm{df}$ & 113 & 168 \\
$\chi^{2} / \mathrm{df}$ & 2.539 & 2.12 \\
Root mean square error of approximation (RMSEA) & 0.078 & 0.067 \\
Standardized root mean square residual (SRMR) & 0.049 & 0.048 \\
Goodness-of-fit index (GFI) & 0.830 & 0.850 \\
Comparative fit index (CFI) & 0.912 & 0.917 \\
Incremental fit index (IFI) & 0.914 & 0.919 \\
\hline
\end{tabular}



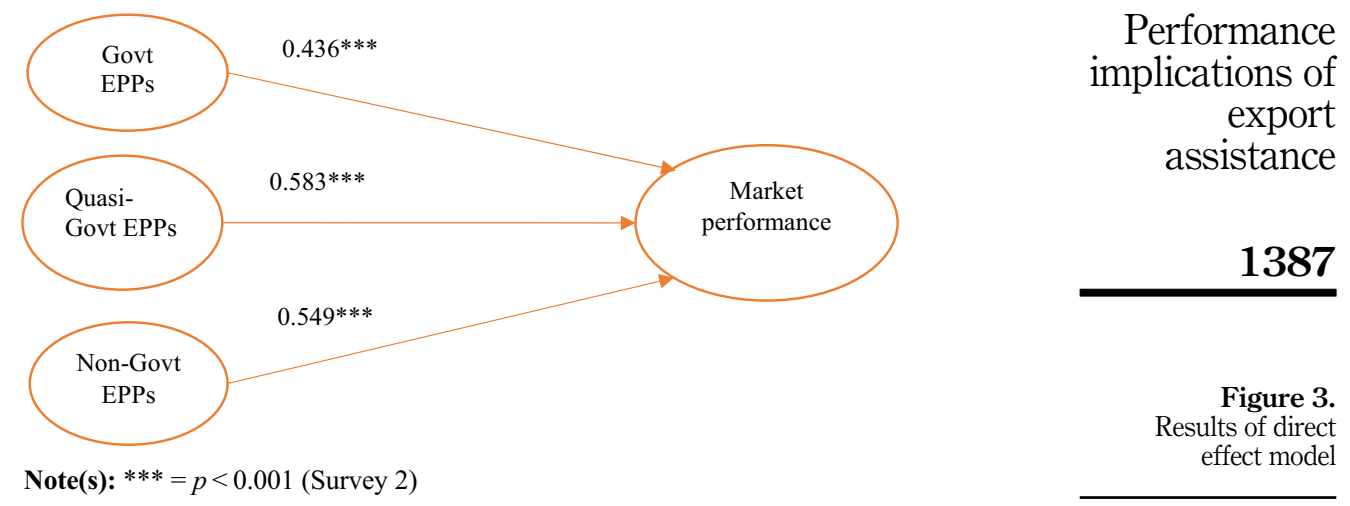

\begin{tabular}{|c|c|c|c|c|c|}
\hline \multirow[b]{2}{*}{ Variables } & \multirow[b]{2}{*}{ Type of effects } & \multicolumn{2}{|c|}{ International EO } & \multicolumn{2}{|c|}{ Market performance } \\
\hline & & Beta & c.r & Beta & c.r \\
\hline \multirow[t]{3}{*}{ Govt. EPPs } & $\mathrm{DE}$ & $0.287^{*}$ & 3.278 & $0.217^{*}$ & 1.634 \\
\hline & $\mathrm{IE}$ & - & - & $0.237 *$ & 1.550 \\
\hline & TE & - & - & $0.455^{*}$ & 1.653 \\
\hline \multirow[t]{3}{*}{ Quasi-govt. EPPs } & $\mathrm{DE}$ & $-0.285^{*}$ & 3.263 & $0.382^{*}$ & 1.512 \\
\hline & $\mathrm{IE}$ & - & & $-0.171 \mathrm{n} . \mathrm{s}$ & -1.02 \\
\hline & TE & - & & $0.211^{*}$ & 2.460 \\
\hline \multirow[t]{3}{*}{ Non-govt. EPPs } & $\mathrm{DE}$ & $0.358^{*}$ & 4.952 & $0.264^{*}$ & 2.777 \\
\hline & $\mathrm{IE}$ & - & - & $0.288^{*}$ & 3.260 \\
\hline & $\mathrm{TE}$ & - & - & $0.552^{*}$ & 3.494 \\
\hline \multirow[t]{3}{*}{ InternationalEO } & $\mathrm{DE}$ & - & - & $0.375^{*}$ & 3.952 \\
\hline & IE & - & - & - & - \\
\hline & TE & - & - & - & - \\
\hline
\end{tabular}

Note(s): * $p<0.05$

ns = not significant; DE: direct effect; IE: indirect effect; TE: total effect

Table 9.

(Survey 2)

Standardized direct, indirect, and total effects of causal variables in the mediation model

The results of survey 2 were akin to those of survey 1 , supporting the robustness of the study findings. The relationships between EPPs from the three different groups and market performance were positive and significant (H1). After we introduced the mediator (international EO) to the structural model, we found government and nongovernment EPPs to be positively and significantly related to international EO but quasi-government EPPs to be negatively and significantly related to EO. Thus, the results from survey 2 confirmed that, after singling out quasi-government EPPs from government EPPs (as opposed to what we combined in survey 1), the direct effect of government EPPs on EO was positively significant, while it was negatively significant for quasi-government EPPs (as opposed to a combined negative nonsignificant effect in survey 1). As for direct effects, EO strongly and positively influenced market performance, supporting H3.

Government EPPs had both direct and indirect positive significant effects on market performance, indicating a partial mediation, whereas quasi-government assistance had positive significant direct effects and negative but nonsignificant indirect effects, ultimately reducing the total effects. Again, as in survey 1, nongovernment EPPs in survey 2 had both direct and indirect significant effects on international performance, indicating a partial mediation. Out of three control variables (firm age, size and industry), only firm size had a significant impact on market performance $(\beta \mathrm{S}=0.218, p<0.05)$. 
IMR

38,6

1388

\section{Discussion}

This study highlights the importance of export entrepreneurship in achieving the performance benefits of EPPs. Governmental/quasi-governmental and non-national EPPs were differentiated, and they were found to lead to differing outcomes with respect to export performance and international EO. While the positive effect of (quasi-)governmental EPPs on firms' export performance lends support to the extant literature (Leonidou et al., 2011; Riddle and Gillespie, 2003), the positive impact of nongovernmental EPPs on performance is a new contribution of this study and supports our nuanced approach of testing it separately. This emphasizes the prominent role of nongovernmental institutions in the development of the industry (Seringhaus and Rosson, 1990) and the export of SMEs (Peng and Ilinitch, 1998).

The positive significant relationship between international EO and export performance lends support to prior EO studies in an export context (Acosta et al., 2018; Karami and Tang, 2019) and confirms that EO significantly contributes to export performance. However, when we interpret the effect of nongovernment assistance on EO and its effect on export performance, it suggests that international $\mathrm{EO}$ alone is not sufficient to guarantee the export performance (Walter et al., 2006) without nongovernmental assistance. Reported significant positive direct and indirect impacts of nongovernmental EPPs on export performance suggest that the resources mobilized from external nongovernmental sources can foster performance both directly and partially mediated by EO (Ireland et al., 2003).

Finally, although the unexpected negative (but nonsignificant) relationship between (quasi-)governmental EPPs and international EO (survey 1) was surprising from the outset, in survey 2 we found that this happened because of the combined effects of national and quasi-national EPPs. After separating the effects of national and quasi-national EPPs in survey 2, we observed the negative significant effects of quasi-governmental assistance on EO and the positive significant effects of governmental EPPs. This negative impact of assistance provided by quasi-national exporters' associations can be attributed to the strong influential role and power politics of exporters' associations in Bangladesh that may have hampered entrepreneurial initiatives of some exporting firms. Since the country's transition from competitive authoritarianism to competitive clientelism in the early 1990s, successive democratically elected governments have relinquished more and more authority to apparel exporters' associations (Ahmed et al., 2014). The government's delegation of the authority to these associations streamlined the process for apparel manufacturers to acquire imported raw materials and technology. Being members of the Parliament and/or having control over mass media, many members of these associations increasingly influence government policies to regulate and administer exports as the members of high-level government committees and through lobbying (Transparency International, 2016).

\section{Implications for researchers}

This study offers some important implications for export assistance researchers. First, including international EO in the export assistance-performance literature gives researchers an opportunity to focus on a much wider management framework, consisting of traditional management terminology and such variables as strategy, performance and organizational structure (Wiklund, 1999). This is the novelty of the study, which highlights the importance of entrepreneurial aspects in the export assistance-export performance relationship. Second, this study is one of only a few that have investigated the indirect relationship between export assistance and performance to validate past findings for generalization. More generally, it contributes to the incomplete understanding of the process ("black box") through which resources influence performance (Miao et al., 2017). Third, investigating the export entrepreneurial aspects and export assistance in the context of an emerging economy provides a much-needed "context contribution" to the extant literature and contributes to 
filling this gap. Finally, the incorporation of the institutional framework in the export performance literature contributes to the understanding of the impact of the incentives embodied in institutional arrangement (North, 1990) and how the institutional context promotes or inhibits entrepreneurship (Veciana and Urbano, 2008). Our special contribution in this regard is the investigation of the impact of EPPs from three different types of institutional sources, which has not been investigated before.

The negative impact of quasi-governmental assistance on international EO suggests that antecedent variables widely accepted as beneficial may in fact be harmful. Our results open the unique institutional arrangements of emerging and developing countries for researchers to revise existing theoretical frameworks to accommodate such institutional peculiarity. The prevailing corruption in developing countries in particular may have negated some of the positive effects of assistance on international EO and performance. Corruption in these countries may play a dual role, serving as both "grease" and "sand" for IE (Chowdhury et al., 2015). Duty exemptions and refunds for imports for exporters in Vietnam are arbitrary and are sometimes subject to corruption and the unofficial taxation of exporters (Martin et al., 2003); Cambodia's corruption and bureaucratic systems also disfavor apparel exporters (Tang, 2016). However, how exporters manipulate bureaucratic systems and expose themselves to corruption and bribery can constitute an important research agenda. Corruption is also common in other developing countries, and future research could investigate such practices in such countries involved in international business. Otherwise, theoretical assumptions originating from developed Western countries will fall short of validation in emerging and developing nations. For example, Malca et al. (2020) and Quaye et al. (2017) investigated the influence of several EPPs provided by the governments of Peru and Ghana, and reported a simplified positive relationship. The results of the present study demonstrate the significance of including business associations (quasi-governmental) and nongovernment entities as export assistance providers in evaluating their influence in a country with rampant corruption and politically influential business associations (Kraus, 2002).

Overall, it seems that research in the export assistance field has solely considered the EPPs sponsored by government, providing an overarching positive view of such assistance; this was demonstrated in Coudounaris's (2018) meta-analysis, in which all these models were described as purely "economic." Coudounaris (2018) called for the inclusion of sociological models involving trust relationships between partners. Our model and findings also require researchers to include political models because business associations, including exporters' associations, constitute a more significant political entity in developing economies (Laothamatas, 2019) and may define the boundary of business-state relationships. In their theoretical paper, Gillespie and Riddle (2004) emphasized the powerful civic and political role of business associations in the Cambodian cut-flower export industry, established in 1970. Although Lucas (1997) stated that business associations cannot independently transform a corrupt system and are less susceptible to rent-seeking, our results indicate that the opposite is true today in developing countries such as Bangladesh.

\section{Implications for managers and policymakers \\ Implications for managers}

This study offers some important implications for entrepreneurs and managers of exporting firms in developing economies. The results suggest that exporters can improve export performance through EPPs from all three types of providers. However, to improve export entrepreneurship, it would not be wise to rely too much on EPPs provided by quasi-national exporters' associations due to their negative effect on international EO. Export managers must be cognizant of the delicate process through which EPPs by different providers create 
IMR

38,6

an enhanced performance (dis)advantage with the mediation of international EO. For example, managers can achieve enhanced international performance benefits from government and non-government EPPs through EO, which ultimately turn into performance disadvantage in the presence of quasi-government EPPs if mediated by EO.

The combined results of these three types of assistance also imply that exporters would be prudent to balance these EPPs, as they mitigate the negative influence of quasi-government assistance on export entrepreneurship via their close collaboration with external partners and mobilizing resources from government and private providers. Exporters should thus focus on their internal entrepreneurial capabilities and mobilize external resources from government and nongovernmental network partners to build trustworthy, sustainable relationships (Saleh et al., 2014) while simultaneously capitalizing on quasi-governmental assistance to promote better export performance. Although this ambidextrous focus on different assistance providers requires more resources on part of exporters, it may enable a balance between entrepreneurial and export performance objectives. Our findings also reinforce the idea that the development of international EO in firms should be supported. While owner-managers' sociocultural characteristics, including education and experience, influence firms' EO (Altinay and Wang, 2011), an organization-wide EO towards foreign markets may be further reinforced by employing managers with prior experience and a global vision (Faroque et al., 2020).

This study also provides important and unique implications for the managers of importing firms, mostly from developed Western countries. This research highlights the corrupt practices and power politics of quasi-government exporters' associations in those developing nations that are making strides in the world export market. Most importers from developed countries maintain a close relationship with exporters' associations in developing countries, and our research cautions them about dealing with exporters and quasigovernment agencies in developing countries. While these importers always strive to force exporters to abide by labor laws, maintain a healthy work environment and pay adequate wages, they may find these agencies and their members avoid such compliance. These quasigovernment agencies are the main stakeholders and the main entities the importers must negotiate with in terms of compliance.

\section{Implications for policymakers and society}

This study offers some guidelines for public policymakers involved in promoting export entrepreneurship and performance. Lefebvre et al. (2003) suggested that governmental assistance programs target the most powerful determinants of export performance. In this study, international EO appears to be the most influential factor for achieving export performance. Based on Lefebvre et al.'s (2003) suggestion and because international EO appears to be the "surrogate" mediator in the export assistance-export performance relationship, governmental bodies could evaluate the magnitude of international EO of exporters based on proactiveness, innovativeness and risk-taking behavior. They could also extend more support to entrepreneurial firms, thereby acknowledging that these firms benefit more from export assistance in the form of export performance. Leonidou et al. (2015), among others, pointed out that one area in EPP services focused on such motivational aspects as "how to motivate firms to embark on exporting." However, it must be noted that the government must first implement an efficient and transparent method of measuring exporters' international EO. Failing to do so could exacerbate the corruption and discrimination already rampant in most developing countries, including Bangladesh.

While international EO is strongly and positively associated with national and nonnational EPPs, its relationship to quasi-government EPPs is negatively significant (confirmed in survey 2). This suggests that quasi-national institutes have failed to stimulate the entrepreneurial-oriented outcomes of internationalizing firms despite the wide 
array of export assistance programs they have in place for exporters, implying that these agencies' focus is no longer the entrepreneurial outcomes of exporters but now export growth and market performance. Given that a unilateral focus on export performance is hurting exporters' entrepreneurial performance, the government should exert influence on the exporters' associations to reorient their focus on EO. This would encourage entrepreneurship, higher value addition and innovative performance. Government agencies must also curb the power of exporters' associations as pseudo-ministries.

Government agencies and exporters' associations do not seem to have adequate mechanisms to detect opportunistic behavior and practices within the industry. The government should restructure existing financial assistance programs by reducing the emphasis on cash incentives, income tax rebates and duty-free imports of raw materials. Led by exporters' associations, these schemes promote corruption and bribery in the industry. Corrupt practices are now damaging the entire value chain and becoming entrenched. Apparel buyers use a variety of strategies to cancel orders, including imposing new compliance conditions on suppliers, manipulating compliance reports and making false allegations about product quality. They are also known to cancel orders at will to effectively blackmail exporters into offering discounts on goods (Transparency International Bangladesh, 2013). This has implications for the whole value chain. To respond to changing market conditions and become competitive, the governments of emerging markets could learn from developed countries with regard to revising export promotion policies (Janssen and Helbig, 2018). Finally, the findings of this study have some societal implications, in that export assistance from different providers helps bolster the foreign currency reserve and plays a pivotal role in creating jobs in local economies, which can positively affect the standard of living in emerging economies.

\section{Limitations and future research}

This study focuses mostly on a particular industry: Although survey 2 covers multiple industries, the sample is still dominated by apparel exporters. Across industries there is a natural variance in export strategy and performance, as well as regional/location variation depending on country relations. Future research should investigate the impact of export assistance on the venture level to highlight the role of strategy and regional focus across ventures.

Due to cultural, legal and political differences, philosophies about export promotion may vary across countries (Cavusgil and Yeoh, 1994), so our results should be interpreted with caution. However, the proposed model can be replicated in other emerging economies that aspire to excel in the apparel and other global industries.

The characteristics of owner-managers (e.g. prior industry or managerial experience) may determine the search for and use of assistance programs (Faroque et al., 2021b); these characteristics were not included in this study. Future studies should examine how exporters' innovation and marketing capability affect the relationships between the hypothesized focal variables. Furthermore, firms at different stages of internationalization could have different needs for assistance in terms of their international EO, and different assistance programs may influence them in distinct ways. The impact of different export assistance programs on different dimensions of international EO, including competitive aggressiveness and autonomy (as suggested by Lumpkin and Dess, 1996), should be investigated to advance the research in this area. Other strategic orientations, such as market orientation and technological orientation, could also be included to elucidate the impacts on and of export assistance. Including the corruption index and its influence on the use of export assistance to promote or inhibit international EO in a cross-country sample can also bring new insights to this field of research. EPPs alleviate institutional voids in emerging countries by providing
Performance implications of export

assistance

1391 
IMR

38,6

market-specific information while exporters target these countries (Dominguez, 2018; Onuklu et al., 2021). However, how local formal and informal institutional voids influence the effectiveness of EPPs may constitute interesting future research. In the presence of formal institutional voids, such informal institutions as NGOs and cooperatives can provide important aid to exporters (Onuklu et al., 2021; Teegen, 2003). Given that market change is a core environmental feature of internationalization (Faroque $e$ t al., 2021a), future research could also investigate how relationships between EPPs, entrepreneurship and performance emerge in a rapidly changing market environment. Finally, future studies should adopt a much more nuanced approach by differentiating three kinds of resources (financial, relational and informational) to disentangle the relative contribution of each type to export performance.

\section{References}

Acosta, A.S., Ángel, H.C. and Jesús, C.A. (2018), "Effect of market orientation, network capability and entrepreneurial orientation on international performance of small and medium enterprises (SMEs)”, International Business Review, Vol. 27 No. 6, pp. 1128-1140.

Ahmed, F.U. and Louis, B. (2019), "An institution-based view of firms' early internationalization: effectiveness of national export promotion policies”, International Marketing Review, Vol. 36 No. 6, pp. 911-954.

Ahmed, F.Z., Anne, G. and Audrey, S. (2014), "The paradox of export growth in areas of weak governance: the case of the ready-made garment sector in Bangladesh", World Development, Vol. 56, pp. 258-271.

Al-Aali, A. and David, J.T. (2014), "International entrepreneurship and the theory of the (long-lived) international firm: a capabilities perspective", Entrepreneurship Theory and Practice, Vol. 38 No. 1, pp. 95-116.

Ali, M.Y. and Shamsuddoha, A.K. (2014), "Impact of export promotion programs on SME export performance: empirical evidence from an emerging nation", in Craig, C.J. (Ed.), Research Handbook on Export Marketing, Edward Elgar Publishing, Cheltenham, UK, pp. 12-40.

Altinay, L. and Wang, C.L. (2011), "The influence of an entrepreneur's socio-cultural characteristics on the entrepreneurial orientation of small firms", Journal of Small Business and Enterprise Development, Vol. 18 No. 4, pp. 673-694.

Arpiainen, R. and Agnieszka, K. (2017), "Learning risk-taking and coping with uncertainty through experiential, team-based entrepreneurship education”, Industry and Higher Education, Vol. 31 No. 3, pp. 143-155.

Barbaroux, P. (2014), "From market failures to market opportunities: managing innovation under asymmetric information”, Journal of Innovation and Entrepreneurship, Vol. 3 No. 1, pp. 1-15.

Barney, J.B., Ketchen, D.J., Jr. and Wright, M. (2011), "The future of resource-based theory: revitalization or decline?", Journal of Management, Vol. 37 No. 5, pp. 1299-1315.

Bhasin, B.B. (2007), "Fostering entrepreneurship: developing a risk-taking culture in Singapore", New England Journal of Entrepreneurship, Vol. 10 No. 2, pp. 39-50.

Broocks, A. and Johannes, V.B. (2017), "The impact of export promotion on export market entry", Journal of International Economics, Vol. 107, pp. 19-33.

Browne, M.W. and Robert, C. (1992), "Alternative ways of assessing model fit", Sociological Methods and Research, Vol. 21 No. 2, pp. 230-258.

Cao, Q., Maruping, L.M. and Takeuchi, R. (2006), "Disentangling the effects of CEO turnover and succession on organizational capabilities: a social network perspective", Organization Science, Vol. 17 No. 5, pp. 563-576.

Catanzaro, A., Messeghem, K. and Sammut, S. (2019), "Effectiveness of export support programs: impact on the relational capital and international performance of early internationalizing small businesses”, Journal of Small Business Management, Vol. 57 No. Suppl. 2, pp. 436-461. 
Cavusgil, S.T. and Yeoh, P.L. (1994), "Public sector promotion of US export activity: a review and directions for the future", Journal of Public Policy and Marketing, Vol. 13 No. 1, pp. 76-84.

Chin, W.W. (1998), "Issues and opinion on structural equation modeling”, MIS Quarterly, Vol. 22 No. 1, pp. vii-xvi.

Chirico, F., Sirmon, D.G., Sciascia, S. and Mazzola, P. (2011), "Resource orchestration in family firms: investigating how entrepreneurial orientation, generational involvement, and participative strategy affect performance", Strategic Entrepreneurship Journal, Vol. 5 No. 4, pp. 307-326.

Chowdhury, F., Audretsch, D.B. and Belitski, M. (2015), "Does corruption matter for international entrepreneurship?”, International Entrepreneurship and Management Journal, Vol. 11 No. 4, pp. 959-980.

Chowdhury, F., Audretsch, D.B. and Belitski, M. (2019), "Institutions and entrepreneurship quality", Entrepreneurship Theory and Practice, Vol. 43 No. 1, pp. 51-81.

Cillo, P., Luca, L.M.D. and Troilo, G. (2010), "Market information approaches, product innovativeness, and firm performance: an empirical study in the fashion industry", Research Policy, Vol. 39 No. 9, pp. 1242-1252.

Clayton, P., Feldman, M. and Lowe, N. (2018), "Behind the scenes: intermediary organizations that facilitate science commercialization through entrepreneurship", Academy of Management Perspectives, Vol. 32 No. 1, pp. 104-124.

Cohen, W.M. and Levinthal, D.A. (1990), "Absorptive capacity: a new perspective on learning and innovation", Administrative Science Quarterly, Vol. 35, pp. 128-152.

Collins, C.J. and Clark, K.D. (2003), "Strategic human resource practices, top management team social networks, and firm performance: the role of human resource practices in creating organizational competitive advantage", Academy of Management Journal, Vol. 46 No. 6, pp. 740-751.

Cooper, A.C., Gimeno-Gascon, F.J. and Woo, C.Y. (1994), "Initial human and financial capital as predictors of new venture performance", Journal of Business Venturing, Vol. 9 No. 5, pp. 371-395.

Coudounaris, D.N. (2018), "Export promotion programmes for assisting SMEs", Review of International Business and Strategy, Vol. 28 No. 1, pp. 77-110.

Courtney, C., Dutta, S. and Li, Y. (2017), "Resolving information asymmetry: signaling, endorsement, and crowdfunding success", Entrepreneurship Theory and Practice, Vol. 41 No. 2, pp. 265-290.

Covin, J.G. and Miller, D. (2014), "International entrepreneurial orientation: conceptual considerations, research themes, measurement issues, and future research directions", Entrepreneurship Theory and Practice, Vol. 38 No. 1, pp. 11-44.

Covin, J.G., Green, K.M. and Slevin, D.P. (2006), "Strategic process effects on the entrepreneurial orientation-sales growth rate relationship", Entrepreneurship Theory and Practice, Vol. 30 No. 1, pp. 57-81.

Cumming, D.J., Grilli, L. and Murtinu, S. (2017), "Governmental and independent venture capital investments in Europe: a firm-level performance analysis", Journal of Corporate Finance, Vol. 42 , pp. 439-459.

Dai, W. and Si, S. (2018), “Government policies and firms' entrepreneurial orientation: strategic choice and institutional perspectives", Journal of Business Research, Vol. 93, pp. 23-36.

Dai, L., Maksimov, V., Gilbert, B.A. and Fernhaber, S.A. (2014), "Entrepreneurial orientation and international scope: the differential roles of innovativeness, proactiveness, and risk-taking", Journal of Business Venturing, Vol. 29 No. 4, pp. 511-524.

Danso, A., Adomako, S., Damoah, J.O. and Uddin, M. (2016), "Risk-taking propensity, managerial network ties and firm performance in an emerging economy", The Journal of Entrepreneurship, Vol. 25 No. 2, pp. 155-183.

Davidson, R. and MacKinnon, J. (2001), "Bootstrap tests: how many bootstraps?", Econometric Reviews, Vol. 19 No. 1, pp. 55-68.
Performance implications of export assistance 
IMR

38,6

Dominguez, N. (2018), "Promotion agencies and SMEs' internationalization process: a blessing or a curse?", Journal of International Entrepreneurship, Vol. 16 No. 1, pp. 58-81.

Dutta, S., Narasimhan, O.M. and Rajiv, S. (2005), "Conceptualizing and measuring capabilities: methodology and empirical application", Strategic Management Journal, Vol. 26 No. 3, pp. 277-285.

Faroque, A.R. and Takahashi, Y. (2012a), "Export assistance: the way back and forward", Export Assistance: the Way Back and Forward: an Empirical Investigation into Developing Country "Born Globals", Springer, New York, NY, pp. 1-23.

Faroque, A.R. and Takahashi, Y. (2015), "Export marketing assistance and early internationalizing firm performance: does export commitment matter?", Asia Pacific Journal of Marketing and Logistics, Vol. 27 No. 3, pp. 421-443.

Faroque, A.R., Mostafiz, M.I., Kuivalainen, O. and Sundqvist, S. (2020), "Prior experience and export performance: the missing link of global vision", International Review of Entrepreneurship, Vol. 18 No. 1, pp. 73-98.

Faroque, A.R., Morrish, S.C., Kuivalainen, O., Sundqvist, S. and Torkkeli, L. (2021a), "Microfoundations of network exploration and exploitation capabilities in international opportunity recognition", International Business Review, Vol. 30 No. 1, doi: 10.1016/j.ibusrev. 2020.101767 .

Faroque, A.R., Torkkeli, L., Mahmud, H. and Kuivalainen, O. (2021b), "Enabling and disenabling boundary conditions of export marketing assistance: an interdisciplinary framework", Journal for Global Business Advancement, Vol. 14 No. 2, pp. 263-283.

Fernández-Mesa, A. and Alegre, J. (2015), "Entrepreneurial orientation and export intensity: examining the interplay of organizational learning and innovation", International Business Review, Vol. 24 No. 1, pp. 148-156.

Fornell, C. and Larcker, D.F. (1981), "Evaluating structural equation models with unobservable variables and measurement error", Journal of Marketing Research, Vol. 18 No. 1, pp. 39-50.

Foss, N. (2011), "Why micro-foundations for resource-based theory are needed and what they may look like. Invited editorial”, Journal of Management, Vol. 37 No. 5, pp. 1413-1428.

Francis, J. and Collins-Dodd, C. (2004), "Impact of export promotion programs on firm competencies, strategies and performance: the case of Canadian high-technology SMEs", International Marketing Review, Vol. 21 Nos 4/5, pp. 474-495.

Freeman, J., Carroll, G.R. and Hannan, M.T. (1983), "The liability of newness: age dependence in organizational death rates", American Sociological Review, Vol. 48 No. 5, pp. 692-710.

Freeman, S., Edwards, R. and Schroder, B. (2006), "How smaller born-global firms use networks and alliances to overcome constraints to rapid internationalization", Journal of International Marketing, Vol. 14 No. 3, pp. 33-63.

Geldres-Weiss, V.V. and Monreal-Pérez, J. (2018), "The effect of export promotion programs on Chilean firms' export activity: a longitudinal study on trade shows and trade missions", Journal of Promotion Management, Vol. 24 No. 5, pp. 660-674.

Geletkanycz, M.A. and Hambrick, D.C. (1997), "The external ties of top executives: implications for strategic choice and performance", Administrative Science Quarterly, Vol. 42 No. 4, pp. 654-681.

Gerbing, D.W. and Hamilton, J.G. (1996), "Viability of exploratory factor analysis as a precursor to confirmatory factor analysis", Structural Equation Modeling: A Multidisciplinary Journal, Vol. 3 No. 1 , pp. $62-72$.

Gillespie, K. and Riddle, L. (2004), "Export promotion organization emergence and development: call to research", International Marketing Review, Vol. 21 Nos 4/5, pp. 465-473.

Haddoud, M.Y., Jones, P. and Newbery, R. (2017), "Export promotion programmes and SMEs' performance: exploring the network promotion role", Journal of Small Business and Enterprise Development, Vol. 24 No. 1, pp. 68-87. 
Hair, J.F., Black, W.C. and Babin, A. (2010), Multivariate Data Analysis: A Global Perspective, PrenticeHall, Upper Saddle River, NJ.

Harmancioglu, N., Grinstein, A. and Goldman, A. (2010), "Innovation and performance outcomes of market information collection efforts: the role of top management team involvement", International Journal of Research in Marketing, Vol. 27 No. 1, pp. 33-43.

Hatcher, L. (2007), A Step-by-Step Approach to Using the SAS System for Factor Analysis and Structural Equation Modeling, SAS Institute, Cary, NC.

Hitt, M.A., Dacin, M.T., Levitas, E., Arregle, J.L. and Borza, A. (2000), "Partner selection in emerging and developed market contexts: resource-based and organizational learning perspectives", Academy of Management Journal, Vol. 43 No. 3, pp. 449-467.

Holmes, R.M., Jr, Zahra, S.A., Hoskisson, R.E., DeGhetto, K. and Sutton, T. (2016), “Two-way streets: the role of institutions and technology policy in firms' corporate entrepreneurship and political strategies", Academy of Management Perspectives, Vol. 30 No. 3, pp. 247-272.

Ibeh, K.I. and Young, S. (2001), "Exporting as an entrepreneurial act - an empirical study of Nigerian firms", European Journal of Marketing, Vol. 35 Nos 5/6, pp. 566-586.

Ireland, R.D., Hitt, M.A. and Sirmon, D.G. (2003), "A model of strategic entrepreneurship: the construct and its dimensions", Journal of Management, Vol. 29 No. 6, pp. 963-989.

Ireland, R.D., Covin, J.G. and Kuratko, D.F. (2009), "Conceptualizing corporate entrepreneurship strategy", Entrepreneurship Theory and Practice, Vol. 33 No. 1, pp. 19-46.

Jambulingam, T., Kathuria, R. and Doucette, W.R. (2005), "Entrepreneurial orientation as a basis for classification within a service industry: the case of retail pharmacy industry", Journal of Operations Management, Vol. 23 No. 1, pp. 23-42.

Janssen, M. and Helbig, N. (2018), "Innovating and changing the policy-cycle: policy-makers be prepared!", Government Information Quarterly, Vol. 35 No. 4, pp. S99-S105.

Jap, S.D. (2001), "Pie sharing' in complex collaboration contexts", Journal of Marketing Research, Vol. 38 No. 1, pp. 86-99.

Karabag, S.F. and Berggren, C. (2014), "Antecedents of firm performance in emerging economies: business groups, strategy, industry structure, and state support”, Journal of Business Research, Vol. 67 No. 10, pp. 2212-2223.

Karami, M. and Tang, J. (2019), "Entrepreneurial orientation and SME international performance: the mediating role of networking capability and experiential learning", International Small Business Journal, Vol. 37 No. 2, pp. 105-124.

Karami, M., Ojala, A. and Saarenketo, S. (2020), "Entrepreneurial orientation and international opportunity development by SMEs: the mediating role of decision-making logic", Journal of Small Business Management, pp. 1-29, (forthcoming).

Katsikeas, C.S., Leonidou, L.C. and Morgan, N.A. (2000), "Firm-level export performance assessment: review, evaluation, and development", Journal of the Academy of Marketing Science, Vol. 28 No. 4, pp. 493-511.

Kenny, B. and Fahy, J. (2011), "Network resources and international performance of high tech SMEs", Journal of Small Business and Enterprise Development, Vol. 18 No. 3, pp. 529-555.

Kim, B.S., Kim, K.B., Park, C. and Lee, J. (2020), "Effects of exhibitors' trade show participation on market performance: longitudinal research", Asia Pacific Journal of Tourism Research, Vol. 25 No. 12, pp. 1343-1358.

Knight, G.A. and Cavusgil, S.T. (2004), "Innovation, organizational capabilities, and the born-global firm”, Journal of International Business Studies, Vol. 3 No. 2, pp. 124-141.

Koppell, J.G. (2006), The Politics of Quasi-Government: Hybrid Organizations and the Dynamics of Bureaucratic Control, Cambridge University Press, Cambridge.

Kraus, J. (2002), "Capital, power and business associations in the African political economy: a tale of two countries, Ghana and Nigeria", Journal of Modern African Studies, Vol. 40 No. 3, pp. 395-436. 
IMR 38,6

Kuivalainen, O., Sundqvist, S. and Servais, P. (2007), "Firms' degree of born-globalness, international entrepreneurial orientation and export performance”, Journal of World Business, Vol. 42 No. 3, pp. 253-267.

Lafferty, B.A. and Hult, G. (2001), "A synthesis of contemporary market orientation perspective", European Journal of Marketing, Vol. 35 Nos 1/2, pp. 92-109.

Lages, L.F. and Montgomery, D.B. (2005), "The relationship between export assistance and performance improvement in Portuguese export ventures: an empirical test of the mediating role of pricing strategy adaptation”, European Journal of Marketing, Vol. 39 Nos 7/8, pp. 755-784.

Laothamatas, A. (2019), Business Associations and the New Political Economy of Thailand: From Bureancratic Polity to Liberal Corporatism, Routledge, New York.

Lee, C., Lee, K. and Pennings, J.M. (2001), "Internal capabilities, external networks, and performance: a study on technology-based ventures", Strategic Management Journal, Vol. 22 Nos 6-7, pp. 615-640.

Lefebvre, E., Bourgault, M., Prefontaine, L. and Lefebvre, L.A. (2003), "Understanding the driving forces behind the internationalisation process of fast-moving SMEs: implications for export assistance programmes", International Journal of Entrepreneurship and Innovation Management, Vol. 3 No. 5, pp. 447-467.

Lengler, J.F., Sousa, C.M. and Marques, C. (2013), "Exploring the linear and quadratic effects of customer and competitor orientation on export performance", International Marketing Review, Vol. 30 No. 5, pp. 440-468.

Leonidou, L.C., Palihawadana, D. and Theodosiou, M. (2011), "National export-promotion programs as drivers of organizational resources and capabilities: effects on strategy, competitive advantage, and performance", Journal of International Marketing, Vol. 19 No. 2, pp. 1-29.

Leonidou, L.C., Samiee, S. and Geldres, V.V. (2015), "Using national export promotion programs to assist smaller firm's international entrepreneurial initiatives", in Ghauri, P.N. and Kirpalani, V.H.M. (Eds), Handbook of Research on International Entrepreneurship Strategy: Improving SME Performance Globally, Edward Elgar Publishing, Cheltenham, UK, pp. 239-252.

Lindell, M.K. and Whitney, D.J. (2001), "Accounting for common method variance in cross-sectional research designs”, Journal of Applied Psychology, Vol. 86 No. 1, pp. 114-121.

Lisboa, A., Skarmeas, D. and Lages, C. (2011), "Entrepreneurial orientation, exploitative and explorative capabilities, and performance outcomes in export markets: a resource-based approach", Industrial Marketing Management, Vol. 40 No. 8, pp. 1274-1284.

Lumpkin, G.T. and Dess, G.G. (1996), "Clarifying the entrepreneurial orientation construct and linking it to performance", Academy of Management Review, Vol. 21 No. 1, pp. 135-172.

Lumpkin, G.T. and Dess, G.G. (2001), "Linking two dimensions of entrepreneurial orientation to firm performance: the moderating role of environment and industry life cycle", Journal of Business Venturing, Vol. 16 No. 5, pp. 429-451.

Luo, Y. and Tung, R.L. (2007), "International expansion of emerging market enterprises: a springboard perspective”, Journal of International Business Studies, Vol. 38 No. 4, pp. 481-498.

Makadok, R. (2001), "Toward a synthesis of the resource-based and dynamic-capability views of rent creation", Strategic Management Journal, Vol. 22 No. 5, pp. 387-401.

Malca, O., Peña-Vinces, J. and Acedo, F.J. (2020), "Export promotion programmes as export performance catalysts for SMEs: insights from an emerging economy", Small Business Economics, Vol. 55, pp. 1-21.

Martin, K., Rajapatirama, S. and Athokorala, P.C. (2003), "Vietnam: deepening reforms for rapid export growth", World Bank Group, paper presented at the International Conference on Vietnam's Readiness for WTO Accession, World Development Sources, WDS, 1998-1, Washington, D.C, available at: https://documents.worldbank.org/en/publication/documents-reports/ documentdetail/917141468762930107/vietnam-deepening-reform-for-growth. 
McDougall, P.P. and Oviatt, B.M. (2000), "International entrepreneurship: the intersection of two research paths", Academy of Management Journal, Vol. 43 No. 5, pp. 902-906.

Miao, C., Coombs, J.E., Qian, S. and Sirmon, D.G. (2017), "The mediating role of entrepreneurial orientation: a meta-analysis of resource orchestration and cultural contingencies", Journal of Business Research, Vol. 77, pp. 68-80.

Morrish, S.C. (2011), "Entrepreneurial marketing: a strategy for the twenty-first century?”, Journal of Research in Marketing and Entrepreneurship, Vol. 13 No. 2, pp. 110-119.

Nakku, V.B., Agbola, F.W., Miles, M.P. and Mahmood, A. (2020), "The interrelationship between SME government support programs, entrepreneurial orientation, and performance: a developing economy perspective", Journal of Small Business Management, Vol. 58 No. 1, pp. 2-31.

North, D. (1990), Institutions, Institutional Change and Economic Performance, Cambridge University Press, New York, NY.

Oliveira, J.S., Cadogan, J.W. and Souchon, A. (2012), "Level of analysis in export performance research", International Marketing Review, Vol. 29 No. 1, pp. 114-127.

Onuklu, A., Hill, T., Darendeli, I.S. and Genc, O.F. (2021), "Poison or antidote: how subnational informal institutions exacerbate and ameliorate institutional voids", Journal of International Management, Vol. 27 No. 1, p. 100806, doi: 10.1016/j.intman.2020.100806.

Oviatt, B.M. and McDougall, P.P. (1994), "Toward a theory of international new ventures", Journal of International Business Studies, Vol. 25 No. 1, pp. 45-64.

Peng, M.W. and Ilinitch, A.Y. (1998), "Export intermediary firms: a note on export development research", Journal of International Business Studies, Vol. 29 No. 3, pp. 609-620.

Peng, M.W. and York, A.S. (2001), "Behind intermediary performance in export trade: transactions, agents, and resources", Journal of International Business Studies, Vol. 32 No. 2, pp. 327-346.

Podsakoff, P.M., MacKenzie, S.B., Lee, J.Y. and Podsakoff, N.P. (2003), "Common method biases in behavioural research: a critical review of the literature and recommended remedies", Journal of Applied Psychology, Vol. 88 No. 5, pp. 879-903.

Putninšs, T.J. and Sauka, A. (2020), "Why does entrepreneurial orientation affect company performance?", Strategic Entrepreneurship Journal, Vol. 14 No. 4, pp. 711-735.

Quaye, D.M., Sekyere, K.N. and Acheampong, G. (2017), "Export promotion programmes and export performance - a study of selected SMEs in the manufacturing sector of Ghana", Review of International Business and Strategy, Vol. 27 No. 4, pp. 466-483.

Riddle, L.A. and Gillespie, K. (2003), "Information sources for new ventures in the Turkish clothing export industry", Small Business Economics, Vol. 20 No. 1, pp. 105-120.

Rosson, P.J. and Ford, I.D. (1982), "Manufacturer-overseas distributor relations and export performance”, Journal of International Business Studies, Vol. 13 No. 2, pp. 57-72.

Roxas, B. and Doren, C. (2013), "Effects of formal institutions on the performance of the tourism sector in the Philippines: the mediating role of entrepreneurial orientation", Tourism Management, Vol. 37, pp. 1-12.

Saleh, M.A., Ali, M.Y. and Julian, C.C. (2014), "International buyer behaviour-commitment relationship: an investigation of the empirical link in importing", International Business Review, Vol. 23 No. 3 , pp. 329-342.

Seringhaus, F.R. (1986), "The impact of government export marketing assistance", International Marketing Review, Vol. 3 No. 2, pp. 55-66.

Seringhaus, F.R. and Philip, J.R. (1990), Government Export Promotion: A Global Perspective, Routledge, New York, NY.

Shamsuddoha, A.K. and Yunus, A.M. (2006), "Mediated effects of export promotion programs on firm export performance", Asia Pacific Journal of Marketing and Logistics, Vol. 18 No. 2, pp. 93-110. 
IMR 38,6

Sharma, R.R., Gloria, S. and Dave, C. (2018), "Export promotion programmes and the export performance of Ghanaian firms: the mediating role of foreign market attractiveness", International Marketing Review, Vol. 35 No. 4, pp. 661-682.

Sim, A.B. and Yunus, A. (1998), "Performance of international joint ventures from developed and developing countries - an empirical study in a developing country context", Journal of World Business, Vol. 33 No. 4, pp. 357-377.

Singer, T.O. and Czinkota, M.R. (1994), "Factors associated with effective use of export assistance", Journal of International Marketing, Vol. 2 No. 1, pp. 53-71.

Sinkula, J.M., William, E.B. and Thomas, N. (1997), "A framework for market-based organizational learning: linking values, knowledge, and behavior", Journal of the Academy of Marketing Science, Vol. 25 No. 4, pp. 305-318.

Sousa, C.M. and Bradley, F. (2009), "Effects of export assistance and distributor support on the performance of SMEs: the case of Portuguese export ventures", International Small Business Journal, Vol. 27 No. 6, pp. 681-701.

Srivastava, R.K., Fahey, L. and Christensen, H.K. (2001), "The resource-based view and marketing: the role of market-based assets in gaining competitive advantage", Journal of Management, Vol. 27 No. 6, pp. 777-802.

Sundqvist, S., Kyläheiko, K., Kuivalainen, O. and Cadogan, J.W. (2012), "Kirznerian and Schumpeterian entrepreneurial-oriented behavior in turbulent export markets", International Marketing Review, Vol. 29 No. 2, pp. 203-219.

Szulanski, G. (1996), "Exploring internal stickiness: impediments to the transfer of best practice within the firm", Strategic Management Journal, Vol. 17 No. S2, pp. 27-43.

Tang, U. (2016), The Recent Development of the Cambodian Garment Industry: Global Firms, Government Policies, and Exports to the US, Doctoral dissertation, Ohio University.

Teece, D.J., Pisano, G. and Shuen, A. (1997), "Dynamic capabilities and strategic management", Strategic Management Journal, Vol. 18 No. 7, pp. 509-533.

Teegen, H. (2003), "International NGOs as global institutions: using social capital to impact multinational enterprises and governments", Journal of International Management, Vol. 9 No. 3 , pp. 271-285.

Transparency International (2016), "Undress corruption: how to prevent corruption in the readymade garment sector: scenarios from Bangladesh", available at: https://www.transparency.de/ fileadmin/Redaktion/Publikationen/2015/Undress_Corruption_TransparencyDeutschland_ 2015_EN.pdf.

Transparency International Bangladesh (2013), "Readymade garments sector: problems of good governance and way forward”, available at: https://blog.transparency.org/wp-content/uploads/ 2014/04/2013_TIB_GarmentSector_EN.pdf.

Uzzi, B. and Lancaster, R. (2003), "Relational embeddedness and learning: the case of bank loan managers and their clients", Management Science, Vol. 49 No. 4, pp. 383-399.

Van de Vijver, F. and Leung, K. (1997), "Methods and data analysis of comparative research", in Berry, J.W., Poortinga, Y.H. and Pandey, J. (Eds), Handbook of Cross-Cultural Psychology, Allyn \& Bacon, Boston, MA, pp. 257-300.

Vasilchenko, E. and Morrish, S. (2011), "The role of entrepreneurial networks in the exploration and exploitation of internationalization opportunities by information and communication technology firms", Journal of International Marketing, Vol. 19 No. 4, pp. 88-105.

Veciana, J.M. and Urbano, D. (2008), "The institutional approach to entrepreneurship research. Introduction", International Entrepreneurship and Management Journal, Vol. 4 No. 4, pp. 365-379.

Verheul, I., Wennekers, S., Audretsch, D. and Thurik, R. (2002), "An eclectic theory of entrepreneurship: policies, institutions and culture", in Audretsch, D.B., Thurik, A.R., Verheul, I. and Wennekers, S. (Eds), Entrepreneurship: Determinants and Policy in a European-US Comparison, Kluwer Academic Publishers, Boston, MA, pp. 11-81. 
Wales, W.J., Patel, P.C., Parida, V. and Kreiser, P.M. (2013), "Nonlinear effects of entrepreneurial orientation on small firm performance: the moderating role of resource orchestration capabilities", Strategic Entrepreneurship Journal, Vol. 7 No. 2, pp. 93-121.

Walter, A., Auer, M. and Ritter, T. (2006), "The impact of network capabilities and entrepreneurial orientation on university spin-off performance", Journal of Business Venturing, Vol. 21 No. 4, pp. 541-567.

Wang, C.L. (2008), "Entrepreneurial orientation, learning orientation, and firm performance", Entrepreneurship Theory and Practice, Vol. 32 No. 4, pp. 635-657.

Wiklund, J. (1999), "The sustainability of the entrepreneurial orientation-performance relationship", Entrepreneurship Theory and Practice, Vol. 24 No. 1, pp. 37-49.

Wilden, R., Gudergan, S.P., Nielsen, B.B. and Lings, I. (2013), "Dynamic capabilities and performance: strategy, structure and environment”, Long Range Planning, Vol. 46 Nos 1-2, pp. 72-96.

Wilkinson, T. and Brouthers, L.E. (2006), "Trade promotion and SME export performance", International Business Review, Vol. 15 No. 3, pp. 233-252.

Yeoh, P.L. (2009), "Realized and potential absorptive capacity: understanding their antecedents and performance in the sourcing context", Journal of Marketing Theory and Practice, Vol. 17 No. 1, pp. 21-36.

Zahra, S.A., Sapienza, H.J. and Davidsson, P. (2006), "Entrepreneurship and dynamic capabilities: a review, model and research agenda", Journal of Management Studies, Vol. 43 No. 4, pp. 917-955.

Zhang, Q. and Fung, H.G. (2006), "China's social capital and financial performance of private enterprises", Journal of Small Business and Enterprise Development, Vol. 13 No. 2, pp. 198-207.

\section{Further reading}

Bagozzi, R.P. and Yi, Y. (1988), "On the evaluation of structural equation models", Journal of the Academy of Marketing Science, Vol. 16 No. 1, pp. 74-94.

Durmuşoğlu, S.S., Apfelthaler, G., Nayir, D.Z., Alvarez, R. and Mughan, T. (2012), "The effect of government-designed export promotion service use on small and medium-sized enterprise goal achievement: a multidimensional view of export performance", Industrial Marketing Management, Vol. 41 No. 4, pp. 680-691.

Faroque, A.R. and Takahashi, Y. (2012b), "The impact of export assistance on 'Born Globals: an integrative network perspective"', Export Assistance: the Way Back and Forward: an Empirical Investigation into Developing Country "Born Globals", Springer, New York, NY, pp. 25-68.

Njinyah, S.Z. (2018), "The effectiveness of government policies for export promotion on the export performance of SMEs cocoa exporters in Cameroon", International Marketing Review, Vol. 35 No. 1, pp. 164-185.

Rajshekhar, M. (2016), "Why India has so many businessmen in parliament", Quartz India, available at: https://qz.com/india/645737/why-india-has-so-many-businessmen-in-parliament/.

Wales, W., Wiklund, J. and McKelvie, A. (2015), "What about new entry? Examining the theorized role of new entry in the entrepreneurial orientation-performance relationship", International Small Business Journal, Vol. 33 No. 4, pp. 351-373.

\section{Corresponding author}

Anisur R. Faroque can be contacted at: anisur.faroque@lut.fi

For instructions on how to order reprints of this article, please visit our website:

www.emeraldgrouppublishing.com/licensing/reprints.htm

Or contact us for further details: permissions@emeraldinsight.com 